\title{
PRESENTATION TO THE
}

MICHIGAN ENVIRONMENTAL

REVIEW BOARD

Ju1y 26, 1976

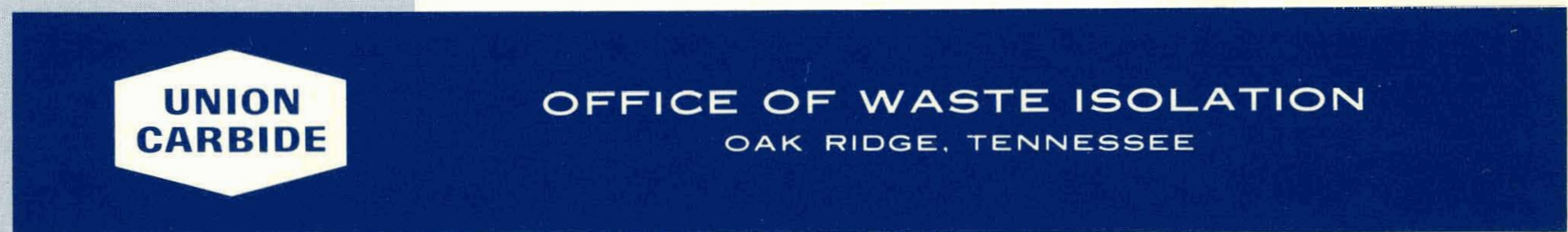

prepared for the U.S. ENERGY RESEARCH AND DEVELOPMENT ADMINISTRATION under U.S. GOVERNMENT Contract W-7405 eng 26 


\section{DISCLAIMER}

This report was prepared as an account of work sponsored by an agency of the United States Government. Neither the United States Government nor any agency Thereof, nor any of their employees, makes any warranty, express or implied, or assumes any legal liability or responsibility for the accuracy, completeness, or usefulness of any information, apparatus, product, or process disclosed, or represents that its use would not infringe privately owned rights. Reference herein to any specific commercial product, process, or service by trade name, trademark, manufacturer, or otherwise does not necessarily constitute or imply its endorsement, recommendation, or favoring by the United States Government or any agency thereof. The views and opinions of authors expressed herein do not necessarily state or reflect those of the United States Government or any agency thereof. 


\section{DISCLAIMER}

Portions of this document may be illegible in electronic image products. Images are produced from the best available original document. 
This report was prepared as an account of work sponsored by the United States Government. Neither the United States nor the Energy Research and Development Administration, nor any of their employees, nor any of their contractors, subcontractors, or their employees, makes any warranty, express or implied, or assumes any legal liability or responsibility for the accuracy, completeness or usefulness of any information, apparatus, product or process disclosed, or represents that its use would not infringe privately owned rights.

\section{COPYRIGHT HOTICE}

BY ACCEPTANCE OF THIS ARTICLE, THE PUBLISHER AUDDCR RE. CIPIENT ACKNOWLEDGES THE U.S. COVERNAENT'S RIGHT TO KETAIN A NONEXCLUSIVE ROYALTY-FREE LICENSE IN AND TO ANY COPYRIGHT COVERING THIS FAIPER. 


\title{
PRESENTATION TO THE \\ MICHIGAN ENYIRONMENTAL \\ REVIEW BOARD
}

JuTy 26,1976

\author{
Compiled By The \\ OFFICE OF WASTE ISOLATION \\ Union Carbide Corporation - Nuclear Division
}

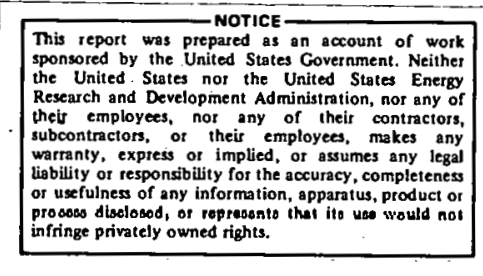




\section{FORWARD}

A general presentation of the National Waste Terminal Storage Program was given on July 26, 1976, to the Michigan Environmental Review Board and the Michigan Nuclear Waste Disposal Task Force. The presentation included the following papers, copies of which are included in this document:

- Nuclear Fuel Cycle and Production

- High Level Waste Solidification

- An Overview of the National Waste Terminal Storage Program

- Background and Review of Investigations in the Salina Salt Basin

- Role of Transportation in the Nuclear Fuel Cycle
F. P. Baranowski, Director Div. of Nuclear Fuel Cycle \& Production, USERDA-HQ

W. F. Bonner, Sr. Research Engineer - Chem. Tech. Dept. Battelle-Pacific Northwest Laboratory

C. D. Zerby, Director OWI, UCC-ND

W. C. McClain, Manager Technical Projects, OWI , UCC-ND

A. F. Perge, Deputy Ass't. Director for Waste Management, DNFCP, USERDA-HQ

Although not presented verbally to the MERB, a sixth paper entitled "Special Technical Issues" by W. C. McClain was distributed to those attending the briefing. A copy of this paper is also included in this document. 
PRESENTATION BEFORE MICHIGAN ENVIRONMENTAL REVIEW BOARD

AND_MICHICAN_NUCLEAR-WASTE-DTSPOSAL_TASK-FORCE

Atti,

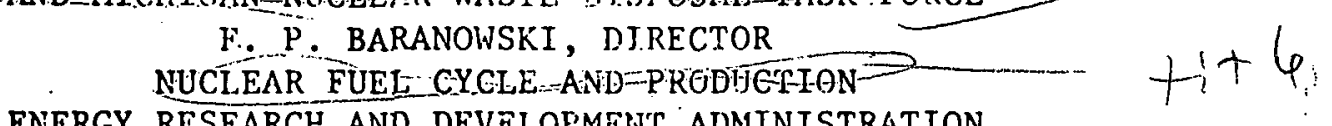

ENERGY RESEARCH AND DEVELOPMENT ADMINISTRATION

JULY 26, 1976

It is a pleasure to have this opportunity to review with you our program to seek within the United States safe, deep geologic storage oites for radioactive wastes.

In our presentation today, we will address some of the questions being raised on the choice of the Salina salt formations, Michigan and the Alpena area for gathering more geologic information.

Because we have not had the opportunity to. discuss in Michigan the . distinction between the geologic isolation program and the other methods of waste management referred to in the press and elsewhere, we plan to Include an introduction to the nuclear fuel cycle, the sources of radioactive waste, status report on the solids which are available for shipment to a deep geologic site, the overall approach to a search for multiple repository sites, and the reasons for the investigations of the Salina salt formations.

In the time period allotted to us, we have conciensed our presentation to permit time to answer questions which you may have on the ERDA program.

Nuclear power, a primary source of energy, is now laking an increasing. role in satisfying the energy needs of the U.S. and the free world. The recent international meeting on radioactive wastes held the week of July 11 in Denver, I believe, has provided an opportunity for many here in the U.S. to obtain a first hand view on the desire of many nations to be less dépendent on fossil fuels. In this country our dwindling supply of oil and gas makes it inperative to $100 \mathrm{k}$ to all reasonable alternative sources of energy to meet our needs. ERDA and other Government agencles have coucluded that coal 
or nuclear are the only significant sources of energy available to the U.S. In the near- and mid-term to substitute for oll and gas in electric power generation. The use of nuclear energy to meet our growth requires a solution to the handling of radioactive wastes safely and with the participation of the public in the decision-makfing process. The effort to a solution on waste management must be a unified one and on a national level. It cannot be solved solely by the Federal Government.

The Energy Research and Development Administration (ERDA) has the responsibility for development of new energy technologies and establishing priorities in development of these energy technologies. The Nuclear Regulatory Commission (NRC) a separate agency, has the responsibility for regulating the safety of the commercial nuclear power industry.

The first chart shows the projected worldwide total and nuclear electrical generating capacity. About $50 \%$ of the total will be nuclear by the year 2000 . In the U.S. the projections are about $25 \%$ nuclear by 1985 and about $50 \%$ nuclear by the year 2000. These projections show that the world will be as dependent, upon nuclear power as the U.S. and that the U.S. growth is equal to the rest of the world. A more detailed breakdown of nuclear power for the midwest is shown on the next chart. The northeast Is also dependent on nuclear power with about the same percent as that of the midwest. The 1985 date is significant since this short time period restricts the forecast to only the firm commitments. With the electric inter-tie networks the entire midwest region is tied to nuclear. More dramatic; the next chart shows the density distribution of nuclear 
reactors in the U.S. It shows the concentration of reactors to be east of the Mississippi and along the west coast.

The next chart shows what would have been the situation if coal had been called upon to substitute for the nuclear electric capacity shown for 1985. By 1985 we would have had to project increases in coal production of one billion tons per year or over $1 \frac{1}{2}$ times the 1974 production output. This growth is considered to be substantial when recognition is given to the essential stable production over the last 10 years. Thus, in this event there would be an even greater uncertainty in the supply of energy in the future.

The next chart shows the front end of the nuclear fuel cycle. Thi's is the mining of uranium, the enrichment of this uranium to fuel grade quality and the fabrication of fuel elements for reactors. The next chart adds the back end of the fuel cycle. This includes reprocessing of spent fuel and the terminal storage of waste from the reprocessing plant. The reprocessing of spent fuel enables the plutonium and uranium to be recycled to the front of the fuel cycle to reduce demands on our natural resources by a significant percentage.

The capital investments by the year 2000 is substantial as shown on the next chart. The number of reprocessing plants is 10 , each costing about $\$ 1$ billion. An enrichment plant of $1 / 3$ the current size of the ERDA complex is $\$ 3.5$ billion and 12 of these are required by the year 2000 if $1 / 3$ of the foreign market is to be satisfied from U.S. piants. 
The resource requirements for fuel cycle activities are shown on the next chart. The energy requirements are 3,000 kwe for a reprocessing plant and the employment is about 1,000 with an annual operating cost of $\$ 50,000,000$. The energy requirements for an enrichment plant are $2,400,000 \mathrm{Kw}$ for a gaseous diffusion process (the existing process at Oak Ridge, Tennessee; Paducah, Kentucky; and Portsmouth, Ohio), but only $200,000 \mathrm{Kw}$ if the new gas centrifuge process, now under development, is used. The annual operating costs of $\$ 500$ million are about the same for each technology but the difference is that the centrifuge process is labor - Intensive whereas the diffusion process has high power costs. The labor force for the centrifuge process is 2,500 to 1,400 for the diffusion process. Because of the highly technical nature of these processes, a large number $\therefore$

of professional and technical personnel are required in designated operation.

The water requirements are 20 million gallons/day and 6 miliion gallons/ day for the diffusion and centrifuge processes, respectively. The reprocessing plant takes only 2 million gallons/day of water for the billion dollar plant noted earlier. The land requirements are 400 acres for the enrichment plant and 150 acres for the reprocessing plant.

The assistance program in each component of the fuel cycle is described briefly.

\section{Uranium Resources}

The ERDA has underway a national uranium resource evaluation program to survey the entire United States. We will use aerial radiometric surveys, water and stream sediment sampling and geologic drilling. This data will assist Industry in exploration for new uranium deposits. 
Uranium Enrichment

The Administration is seeking the passage of a Nuclear Fuel Assurance Act which will provide certain guarantees to U.S. Industry to build the large. enrichment facilities. The Congressional $B 111$ is expected to be scheduled for vote in Congress later this week.

\section{Reprocessing and Recycle}

The ERDA has under review comments it has received from industry on the obstacles to establishing a reprocessing and récycle industry and the Government assistance required to remove these obstacles. No decision has been made but a great deal of activity is underway within the Administration on this component of the fuel cycle.

Thus, the Government is tailoring the type assistance required for each part of the fuel cycle. It's objective is to provide minimur assistance to establish a viable nuclear fuel cycle industry.

The sources of radioactive waste will be shown starting with the nuclear reactor. Radioactive waste from nuclear reactors can be stored in shaliow burial sites as shown in the next slide. There are sites now in operation receiving such wastes. A photograph of one of the sites is shown on the next slide. This is not a deep genlogic'storage site. We have no deep geologic sites avallable at the present time. The opent fuel from the 
reactors can be shipped either to a deep geologic storage formation when avallable or to a reprocessing plant for the recovery of plutonium and uranium for recycle as shown on the next chart. The next chart shows a photo of a fuel element. The low level waste as a solid can go to shallow burial sites similar to the low level waste from nuclear reactors, but the high level waste which contains most of the radioactive fission products is first stored as a liquid in engineered storage tank facilities and after a period of cooling this waste is converted to a solid before it will be transferred to deep geologic storage. The NRC regulations require that the ' liquid waste must be converted to solid within 5 years and shipped to a repository before another 5 years. Deep geologic storage will be in an engineered facility located between 1,000 anf 5,000 feet below the surface to assure the waste will be 1solated from man and, his environment. It is not a dumping operation.

Before concluding my remarks, I would like to introduce Dr. W. F. Eonner who will briefly cover the work done here and abroad on the solidification of liquid radioactive waste.

With these solid forms in mind, the next slide shows our overall concept on the barriers which will be provided to protect the environment. Not shown as a possible additional barrier to the environment is the ability of scil to retain the fission products and plutonium from migrating. The use of this ". added harrier is strongly suggested for certain soils, by natural nuclear reactors which produced tons of fission products and plutonium in a clay formation some two billion years ago. These nuclear events took place 
In an area of the Oklo mine located in the Republic of Gabon, West Africa. All evidence points to the radioactive products belng contained in the near vicinity of these natural nuclear reactors. More work would be needed before such a barrier concept could be relied upon.

To support oür waste management program which includes the search for geologic repositorles, the Administration increased the budget from $\$ 12$ million In 1976 to $\$ 60$ million in 1977 as shown on the next chart. Also, there was a major expansion of effort in the management of the ERDA generated waste. The work on ERDA's waste in most cases can be used in the commercial waste program. Congress in approving the budget for ERDA added $\$ 5.6$ million to the commercial. waste level. Thus, it is reasonable to assume that Congress supports our program to seek a solution to radioactive waste storage at an early date.

In conclusion, our program is one of openness and we believe the press release by $\mathrm{Dr}$. Tanner's office in the Department of Natural Resources of the State of Michigan in February is consistent with our interest in keeping the public fully aware of our work. Further, we have discussed our program before Congress, industry, and in open meetings as in Denver and before other interested groups such as this one today. We will comply fully with the National Environmental Policy Act of 1969 as I stated in the letter to Congressman Ruppe on June 22, 1976. The Council on Environmental Quality (CEQ) In their letter of July 2 to Congressman Ruppe supported to approach outlined in my letter to Congressman Ruppe.

We believe our program is based on a sound background of information: and with the input of both new contractors and state groups we believe that we can arrive at an early and effective national solution. The program 
approach has changed significantly since 1972 when the AEU was looking to the repository location in the salt beds in the Kansas portion of the Permian Basin. Dr. Clayton Zerby will describe our progran and address the Interest in the Salina salt formations. 
VIEWGRAPHS USED AT MICHIGAN PRESENTATION JULY 26, 1976

1. World-Wide Projection of Total and Nuclear Electric Generating Capacity

2. Domestic Nuclear Power Growth - U.S., Midwest, and Michigan

3. Nuclear Power Reactors in the U.S.

4. Increased Demand for Coal

5. Front End of Fuel Cycle

6. Back End of Fuel Cycle

7. Growth of U.S. Nuclear Fuel Cycle Facilities

8. Fuel Cycle Resource Usage

9. Shallow Burial

10. Shallow Burial Photo

11. Fuel Element

12. Geologic Storage

13. Barriers to the Environment

14. Waste Management Budget 


\section{WORLD-WIDE PROJECTION OF TOTAL AND NUCLEAR ELECTRIC GENERATING CAPACITY}

\section{(MILLIONS OF ELECTRIC GENERATING CAPACITY IN SERVICE}

KILOWATTS)

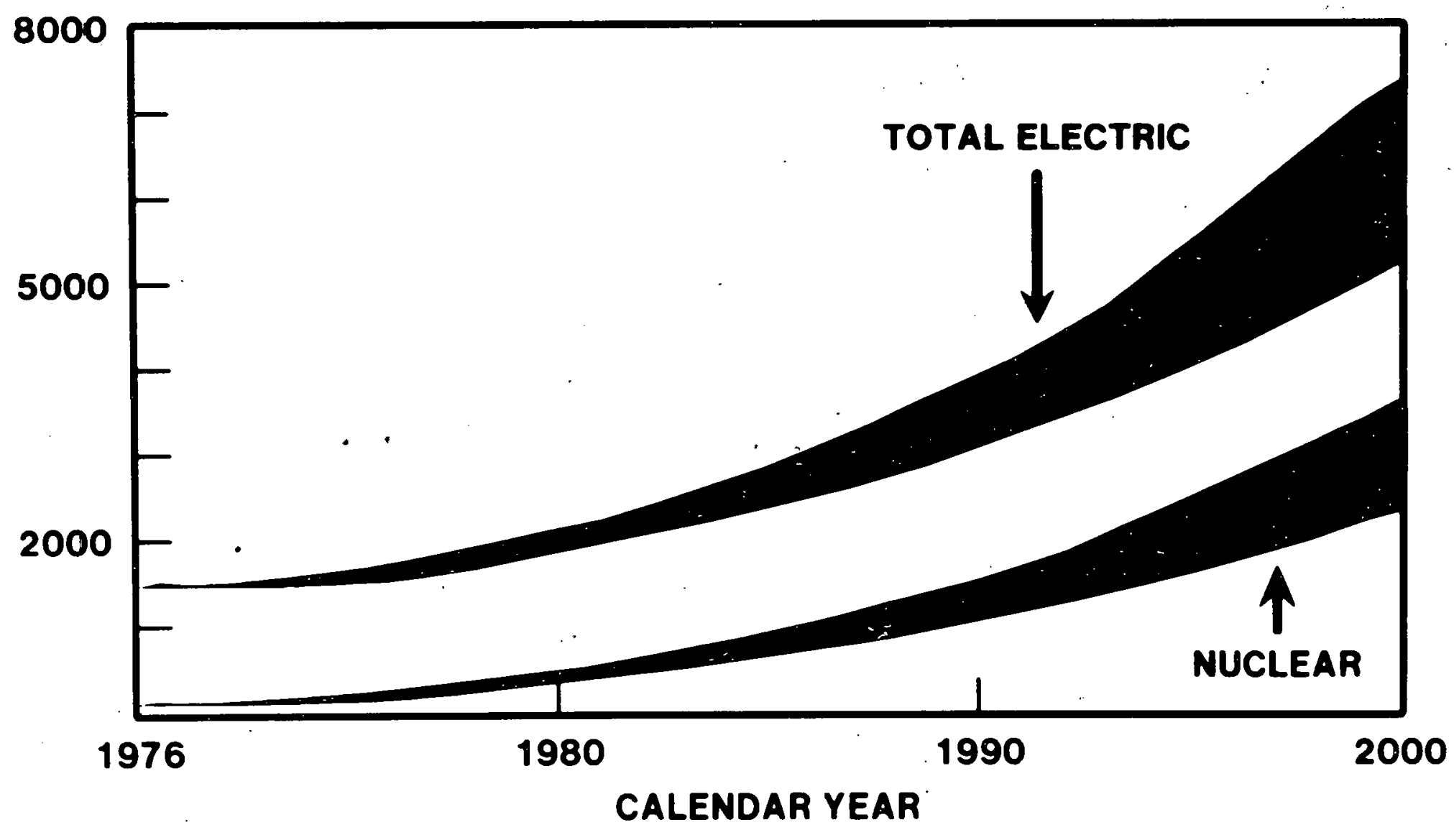




\section{DOMESTIC NUCLEAR POWER GROWTH U.S., MIDWEST, AND MICHIGAN (END OF CALENDAR YEAR)}

KILOWATTS (NUCLEAR)

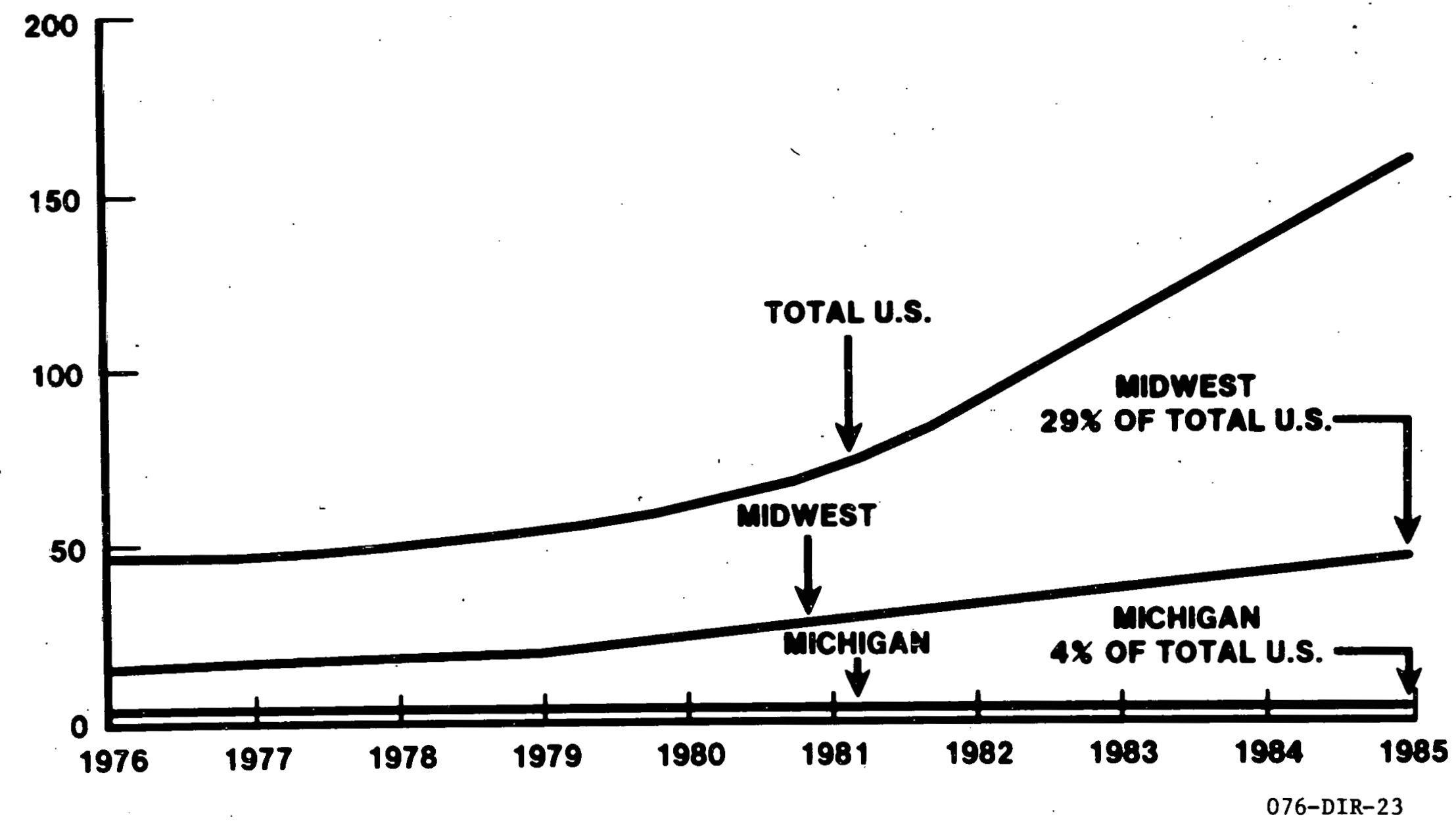




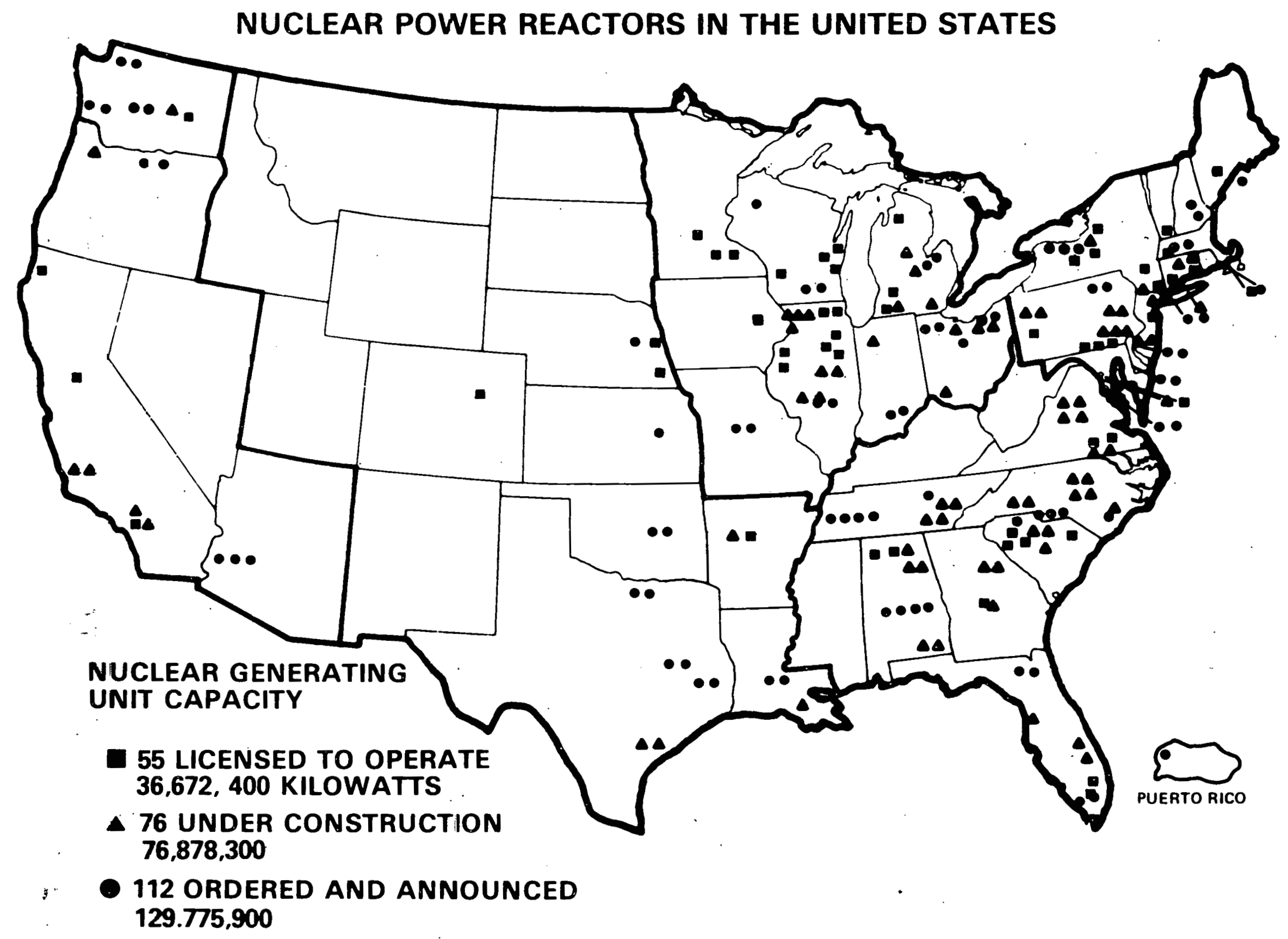




\section{INCREASED DEMAND FOR COAL}

10 YEAR HISTORY OF ACTUAL PRODUCTION COMPARED WITH EXPECTED NEED 10 YEARS IN FUTURE

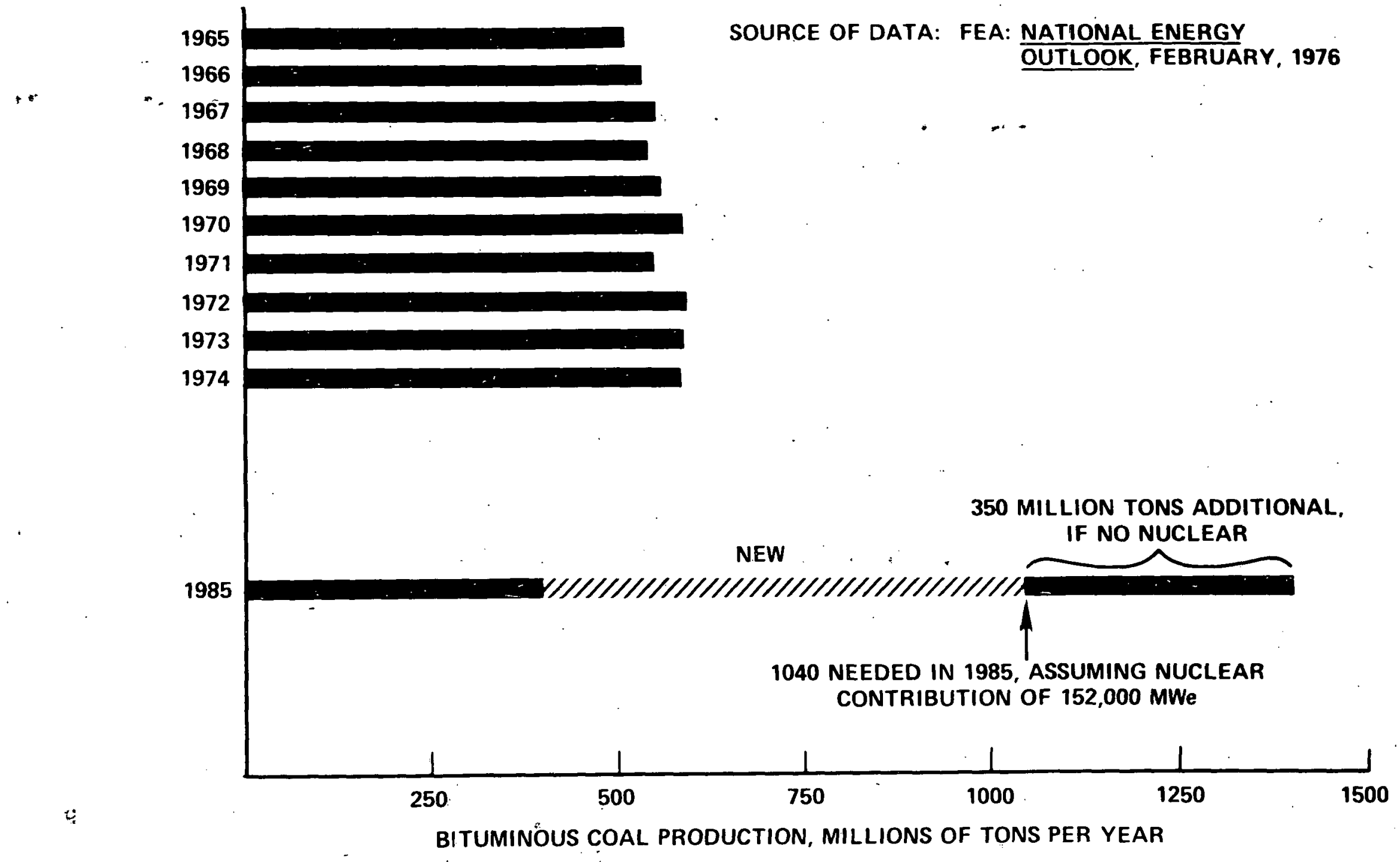




\section{Commercial Nuclear Fuel Cycle}

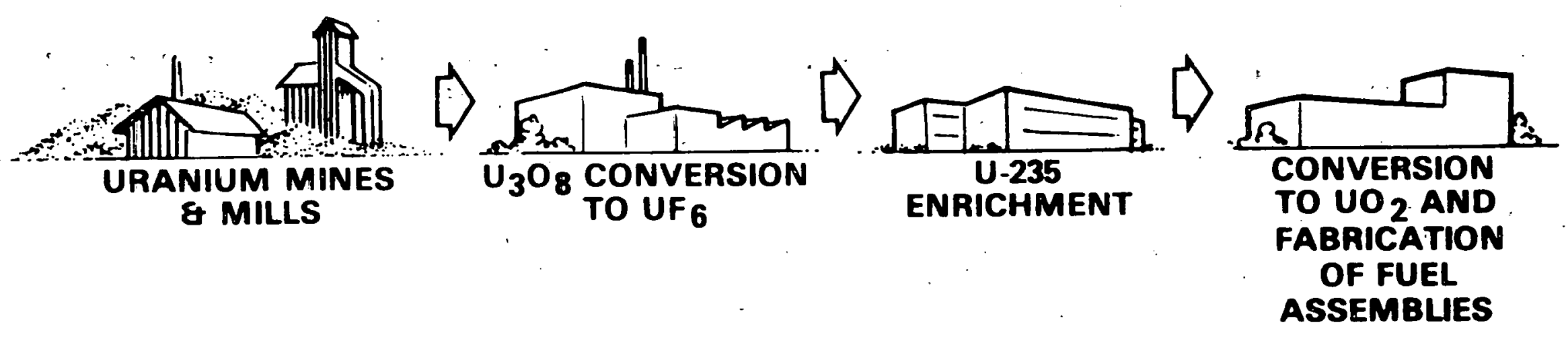




\section{Commercial Nuclear Fuel Cycle}

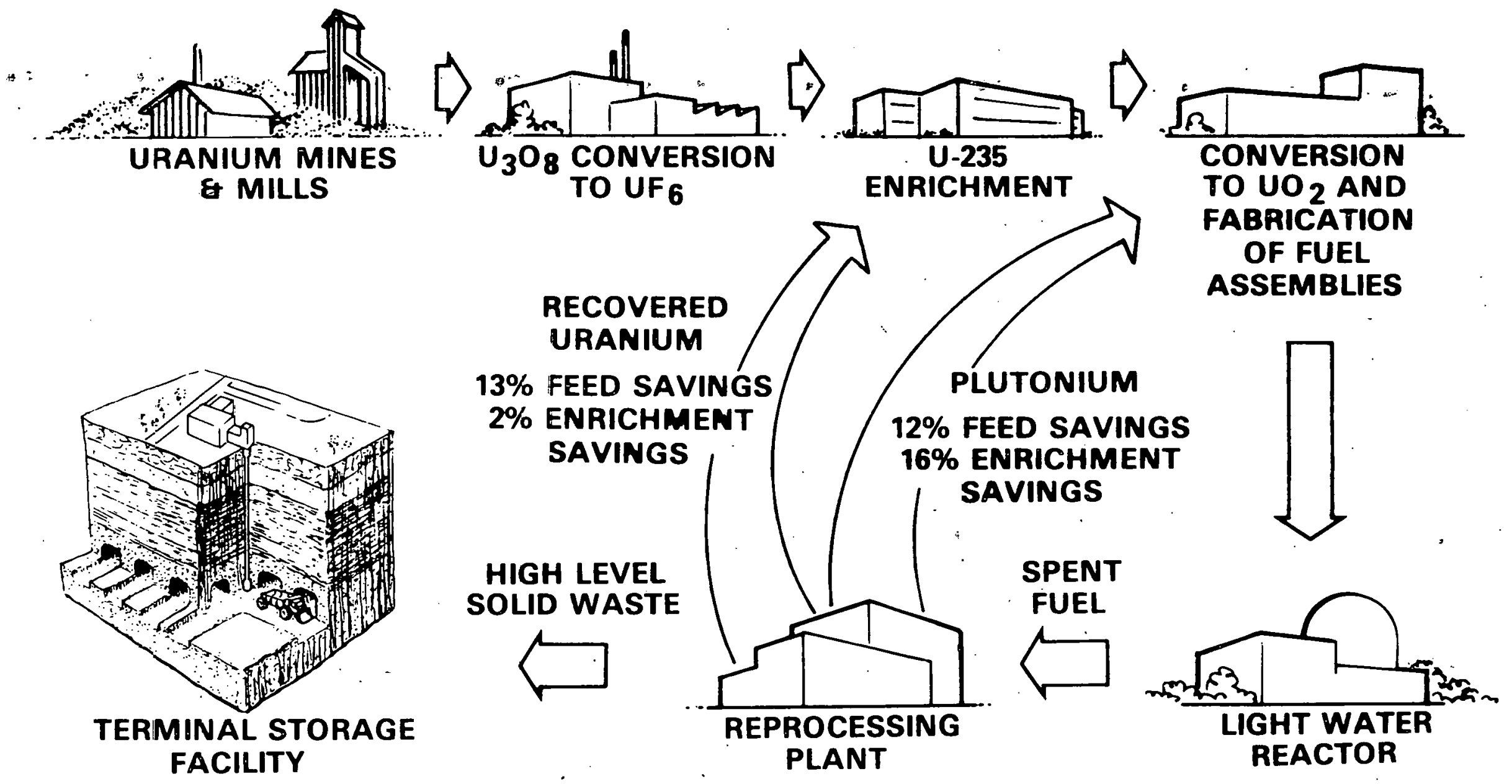


$\therefore$ GROWTH OF U.S. NUCLEAR FUEL CYCLE. FACILITIES

\begin{tabular}{|c|c|c|c|c|}
\hline & & NOW & $\underline{2000}$ & $\begin{array}{l}\text { FACILITY COST } \\
\text { (\$BILLION) } \\
\end{array}$ \\
\hline & $\begin{array}{l}\text { URANIUM RESOURCES } \\
\text { MILLS (1000 T/YR) }\end{array}$ & 19 & 120 & 22 \\
\hline- & $\begin{array}{l}\text { ENRICHMENT PLANTS } \\
9 \text { MILLION SWU (INCLUDES } \\
\text { U:S. SHARE OF FOREIGN) }\end{array}$ & 3 & 12 & 42 \\
\hline- & $\begin{array}{l}\text { REPROCESSING PLANTS FOR } \\
\text { LWR'S }(1500 \mathrm{MT} / \mathrm{YR})\end{array}$ & 0 & 10 & 10 \\
\hline & WASTE STORAGE FACILITIES & - & - & - \\
\hline
\end{tabular}




\section{FUEL CYCLE RESOURCE USAGE}

\begin{tabular}{|c|c|c|c|c|c|}
\hline ACTIVITY & $\begin{array}{l}\text { WATER } \\
\text { MILLIONS OF } \\
\text { GAL/DAY }\end{array}$ & $\begin{array}{c}\text { POWER } \\
\text { THOUSANDS } \\
\text { OF KW }\end{array}$ & $\begin{array}{l}\text { LAND } \\
\text { ACRES }\end{array}$ & EMPLOYMENT & $\begin{array}{l}\text { ANNUAL } \\
\text { OPERATING COST } \\
\text { (\$ IN MILLIONS) }\end{array}$ \\
\hline ENRICHMENT & & & & & . \\
\hline DIFFUSION & 20 & 2400 & 400 & 1400 & 500 \\
\hline CENTRIFUGE & 6 & 200 & 350 & 2500 & 500 \\
\hline REPROCESSING & 2 & 3 & 150 & 1000 & 50 \\
\hline $\begin{array}{l}\text { TERMINAL WASTE } \\
\text { DISPOSAL }\end{array}$ & - & - & 100 & 350 & 15 \\
\hline
\end{tabular}




\section{NUCLEAR FUEL CYCLE (WASTES TO REPOSITORIES)}

SOURCES OF WASTE

TYPE OF REPOSTIORY

FRESH
FUEL
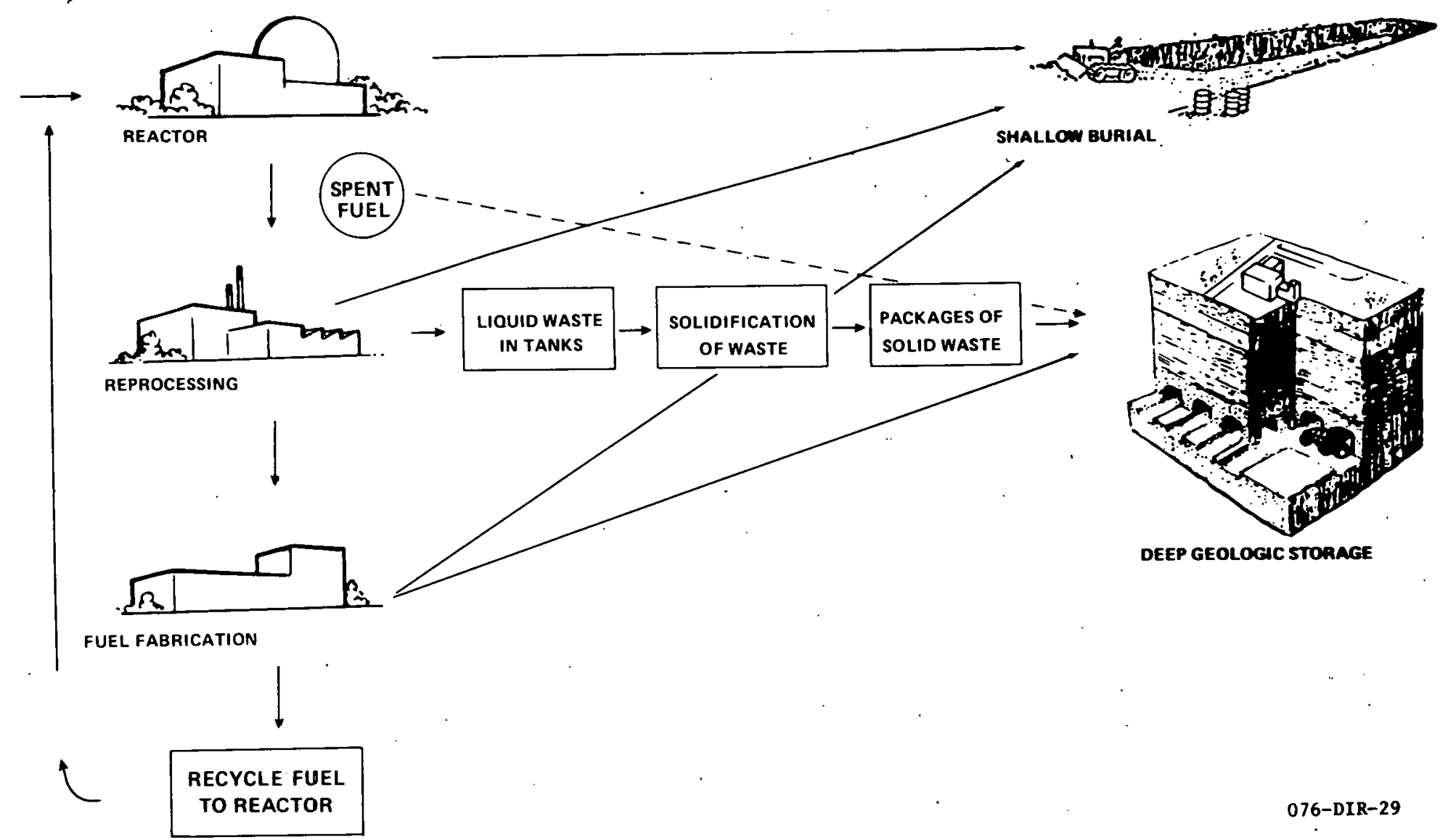

076-DIR-29 

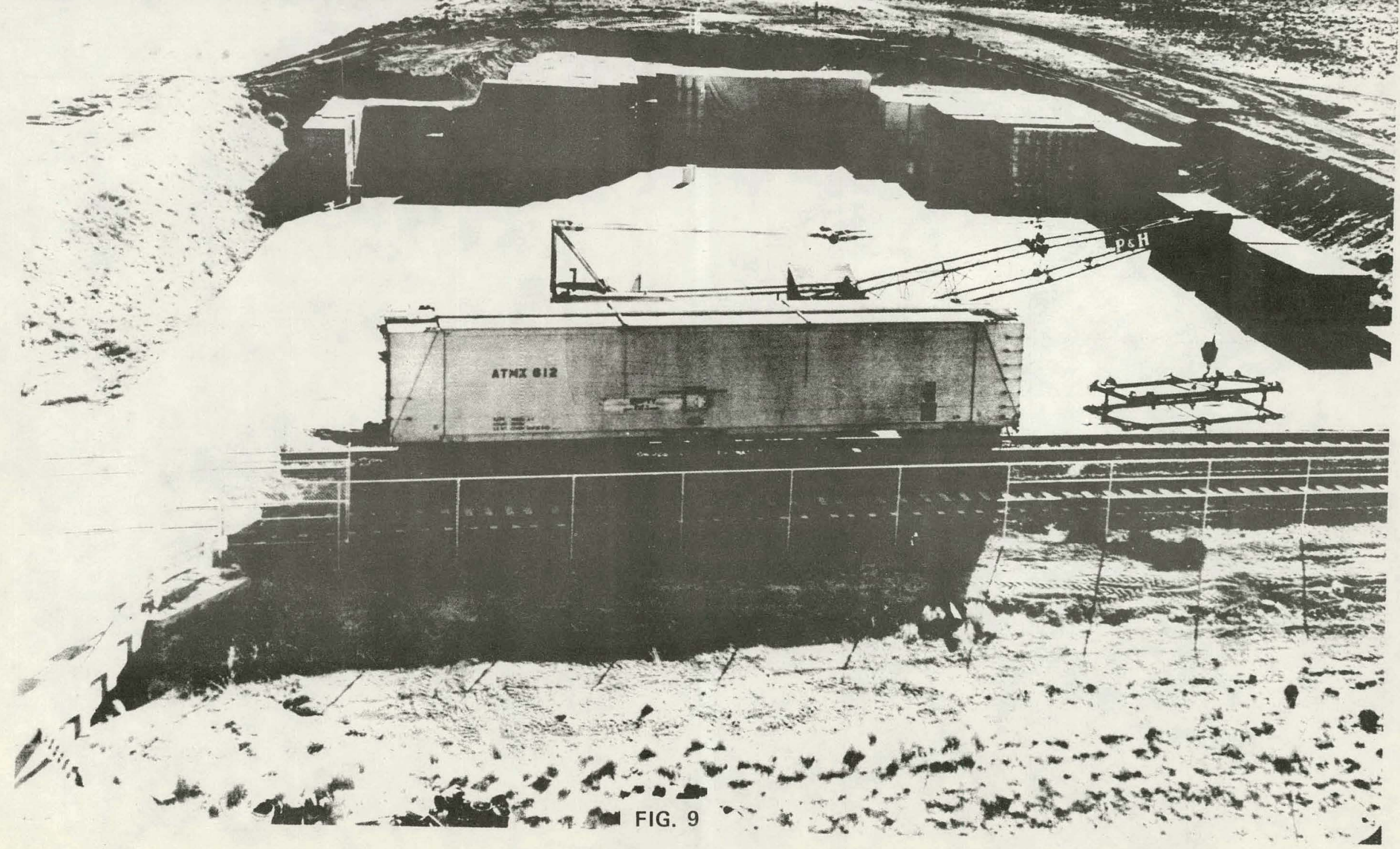


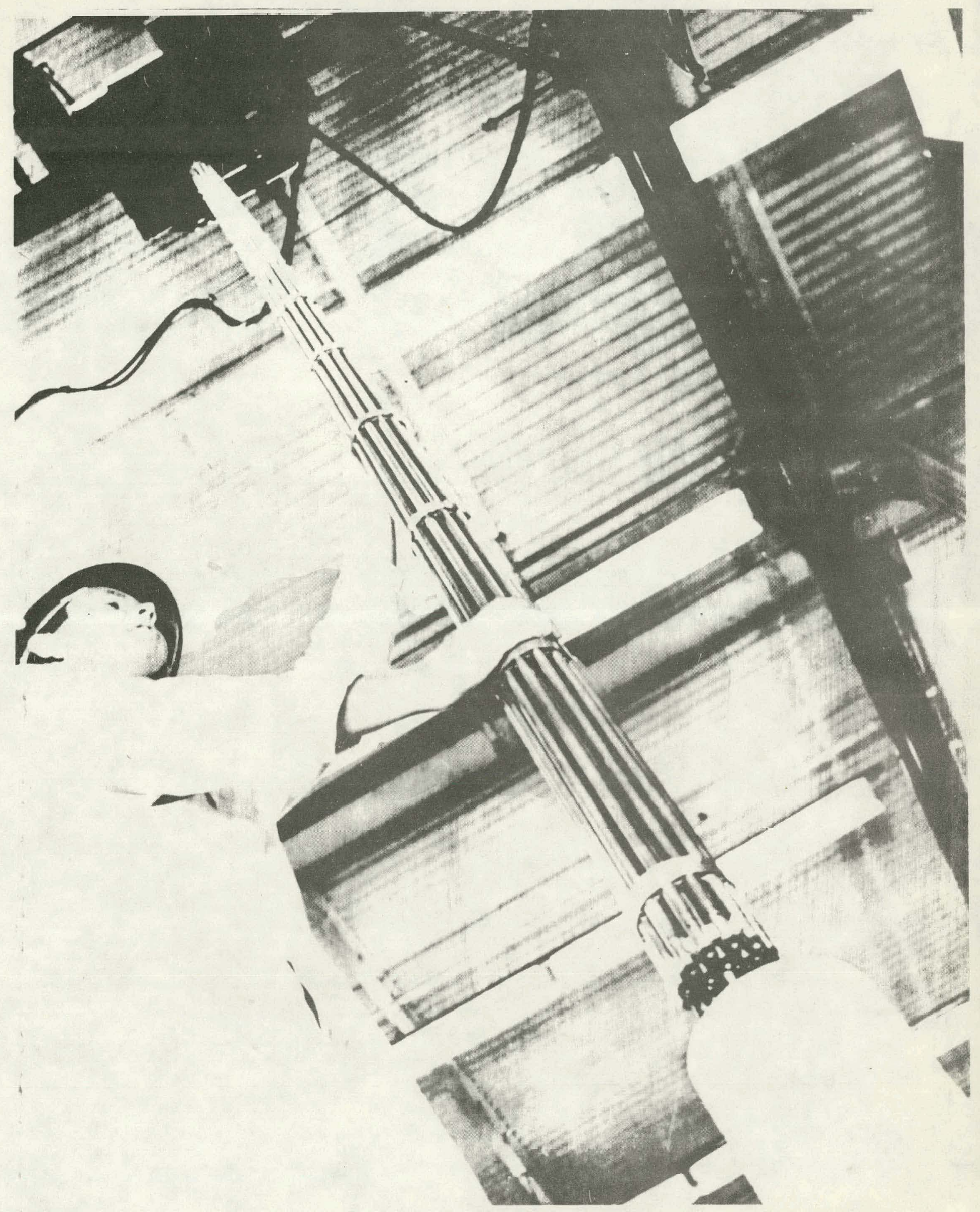




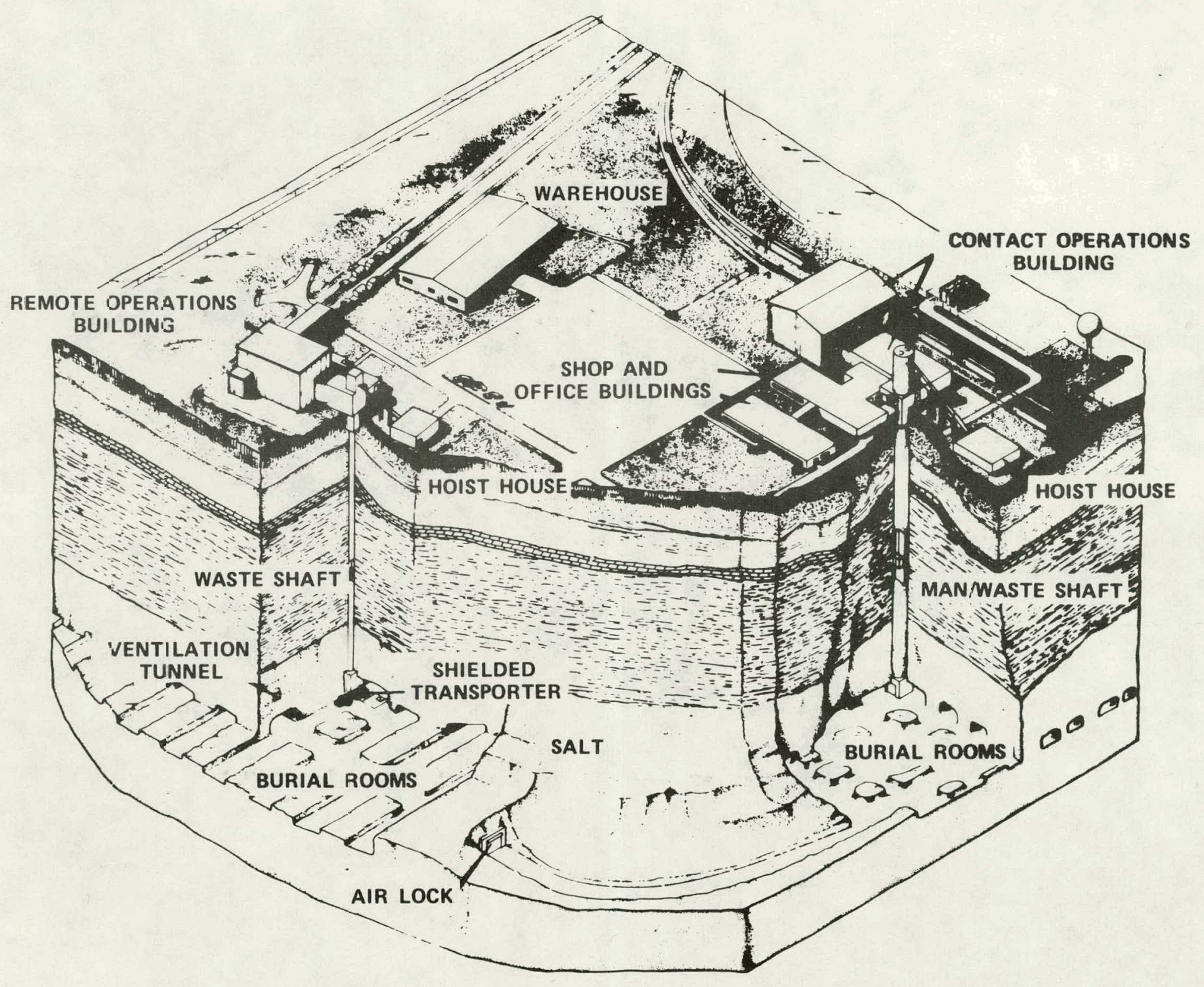

PILOT PLANT CUTAWAY 


\section{BARRIERS TO THE ENVIRONMENT}

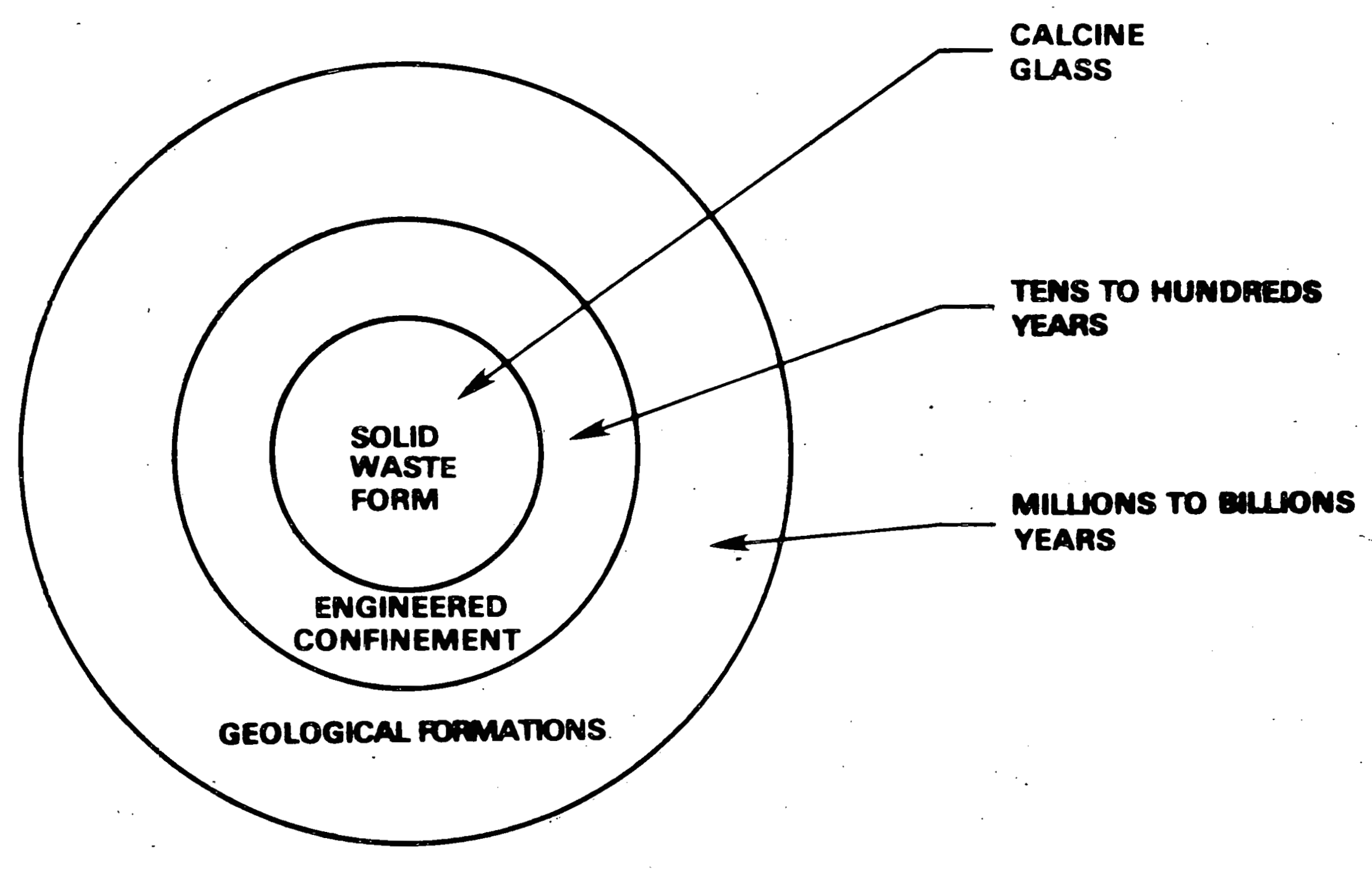




\section{WASTE MANAGEMENT OPERATING BUDGET}

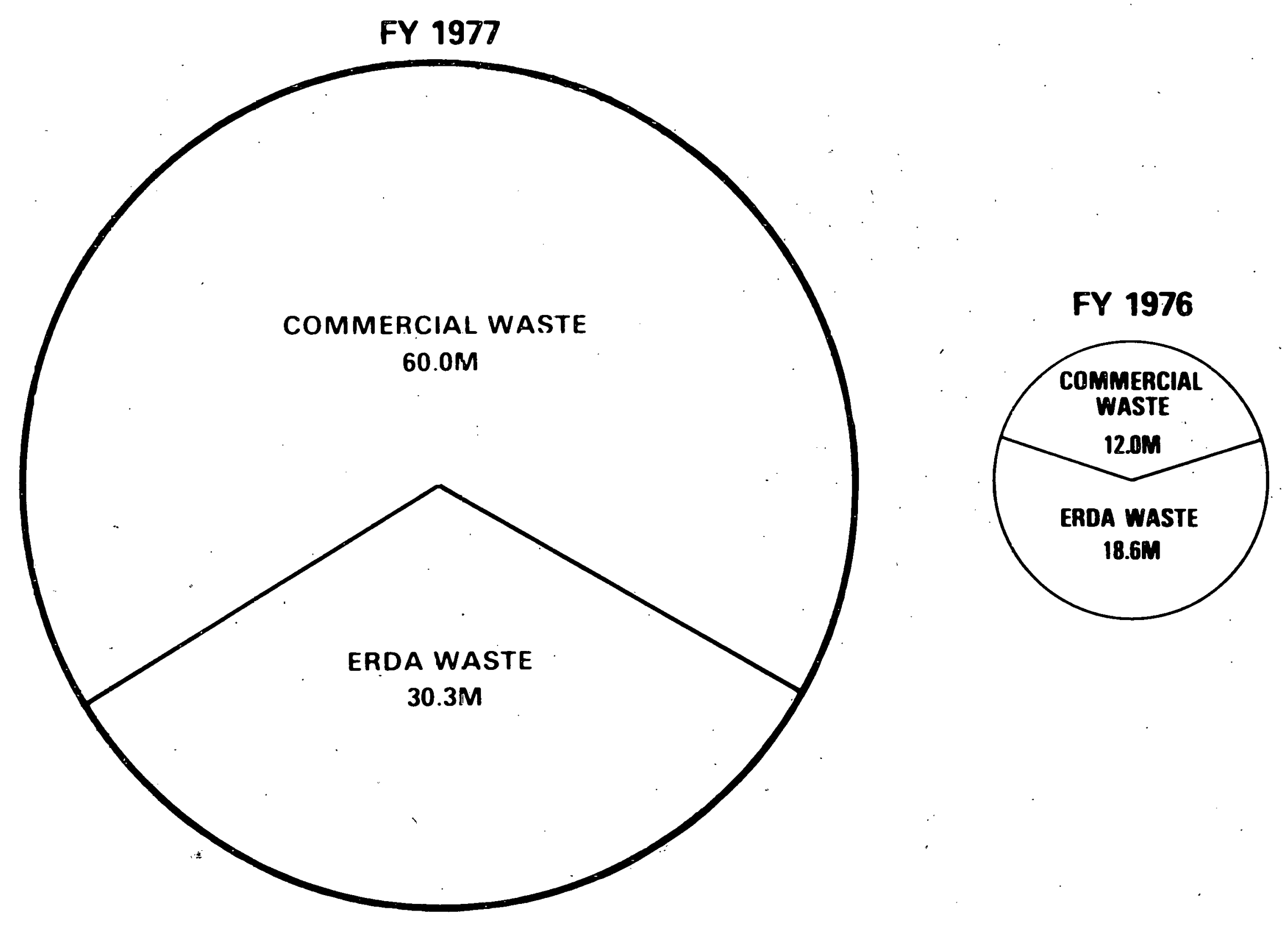




\title{
HIGH LE VEL WASTE SOLIDIFICATION
}

\author{
W. F. Bonner
}

Viewgraphs

1. Calcine and Glass

2. Spray Calciner/

In-Can Melter

Process
Narrative

Current Federal regulation requires that liquid wastes from reprocessing of fuel from commercial nuclear power reactors be converted to a solid within five years of reprocessing. The solid must be stable in terms of its physical and radiochemical properties.

Several processes have been developed for solidifying highlevel liquid waste from nuclear fuel reprocessing. These processes convert liquid waste to a dry powder, called a calcine, or to a solid glass product.

This is an artist's view of one process currently. favored for converting the waste to a glass. It involves two steps: spray calcination, followed by in-can melting.

The liquid waste is sprayed through a nozzle into the heated spray chamber. It evaporates and dries as it falls through the calciner. The resulting powder is mixed with glassforming additives and falls directly into a canister in its in-can melter furnace, where it is melted at more than $1000^{\circ} \mathrm{C}$. to form a glass. 
Filters remove any calcine that follows the off-gas stream, and the off-gas itself is cleaned by auxiliary systems.

This process of in-can melting uses the storage canister as the melting container. When a can is filled, the calcine/frit mix is diverted to a second furnace while the full canister is cooled and removed, welded shut, decontaminated and placed in interim storage.

3. EDL Equipment.

This photograph shows engineering-scale equipment at the Pacific Northwest Laboratory. The calciner/melter equipment has been operated for several years and a full-scale system that will be typical of an actual plant operation is now being built. However, I would like to point out that this operation is of commercial scale. It can handle all of the high and intermediate-level radioactive waste generated by 30 nuclear power reactors.

(more) 
4. B-Cell Equipment

5. Test Canister
We have al ready operated spray calcination and melting equipment with radioactive materials similar to the highlevel waste to be generated by a commercial fuels reprocessing plant. Large canisters of calcine and glass produced during the 1960 's are in storage for evaluation. The canisters--about 8 feet long--have performed well during the decade of our studies on the high-level waste material.

This is one of the 8-inch diameter canisters being prepared

for movement into shielded rooms for filling with radioactive waste glass. Canisters used in the commercial waste management program may be a bit-larger--probably about a foot in diameter and about 10 feet long. After being filled with the waste glass they may be stored in water at the reprocessing site temporarily but then must be shipped to a Federal repository.

An extensive research program is dedicated to fully understanding the properties of the solidified waste and the canisters themselves. We must be able to predict the behavior of these materials during long-term storage. 
6. Drop Test

7. Leach Data
This photograph was taken during one rather severe, but typical, test. This half-scale canister of borosilicate glass was dropped 30 feet onto a concrete pad. The canister did not break open. Removal of the steel wall at the point of impact showed that there was some breakage of the glass, but only at the point of impact.

Impact tests such as this help analyze the safety of handling calcine and waste glass during all phases of canister transportation and storage.

The borosilicate glass is an attractive product for long term waste disposal. For one thing, it is relatively insoluble--an important feature in the unlikely event that water enters the storage medium.

The solubility of typical waste glass is compared here with other man-made materials and some natural minerals.. The glass used in this test is comparable to the well-known Pyrex product, glassware common in chemical laboratories and household cookware. 
We also have tests in progress to thoroughly study thermal and radiation effects on the products. We have produced samples that are equivalent to waste glass after 2,000 years of storage. To date we conclude that borosilicate glass is suitable for long-term storage of high-level waste.

8. Cask on Rail Car

In summary, there are processes now available for converting liquid radioactive wastes to a solid form--a form suitable for long-term storage and safe disposal. The work is continuing and programs are underway to implement this technology in nuclear fuel reprocessing plants. 


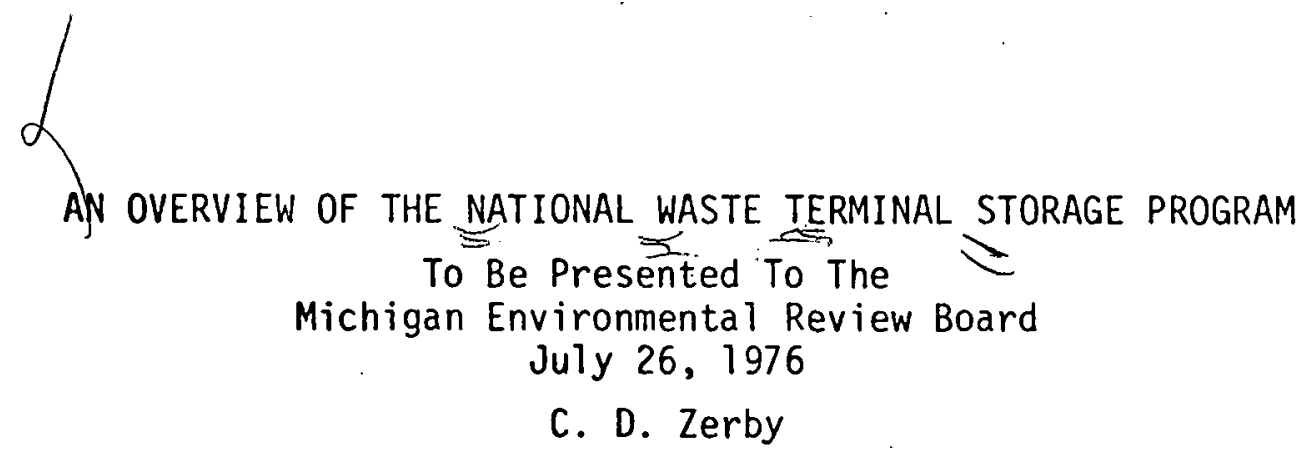

The purpose of this paper is to provide an overview of the National Waste Terminal Storage (NWTS) program that was started in February 1970. The objective of the new program is (see Figure 1):

To provide facilities in various deep geologic formations at multiple locations in the USA which will safely dispose of the commercial radioactive waste which must be delivered to a Federal Repository for terminal storage.

At the present time the only regulations requiring delivery of commercial waste to a Federal Repository are contained in Title 10, Code of the Federal Register (CFR), Part 50, Appendix $F$ (see Figure 2). These regulations refer to licensing of production and utilization facilities, and Appendix $F$ refers to siting reprocessing and related waste management facilities. In brief, Appendix $F$ requires that: (a) a fuel reprocessing plant's inventory of high-level liquid radioactive wastes ${ }^{1}$ will be 1 imited to that produced in the prior five years; (b) high-level liquid radioactive waste shall be converted to a dry solid and placed in a sealed container prior to transfer to a Federal Repository; and (c) all high-level wastes shall be transferred to a Fcderal Repository no later than 10 years following separation of fission products from the irradiated fuel.

Other requirements for shipment of waste to a Federal Repository may be included in changes to Title 10 CFR, Part 20. Regullations in 10 CFR 20 pertain to Standards for Protection Against Radiation. Current proposed

\footnotetext{
1High-level liquid wastes means those aqueous wastes resulting from the operation of the first-cycle solvent extraction system, or equivalent, and the concentrated wastes from subsequent extraction cycles, or equivalent, in a facility for processing irradiated reactor fuels.
} 
changes relate to transuranic waste disposal and will require that waste with contamination levels as low as 10 nanocuries of transuranic elements per gram of waste must be transferred to ERDA for storage as soon as practicable but within five years after its generation (see Figure 3 ). These regulations imply that if reprocessing plants are put into operation, then most certainly high-level waste will be delivered to the Federal Repository and very probably low-level transuranic waste will also be delivered to the facility. In this event, the Federal Repository would be designed to receive both types of waste. If, on the other hand, reprocessing plants are not put into operation, then the Repository will be built to dispose of spent fuel elements.

Figure 4 presents an artist's sketch of what a Federal Repository might look like if it were constructed in a bedded salt formation. Typically, the facility would consist of a large number of excavated rooms located several hundred feet below the surface of the ground. On the surface would be located receiving and handling facilities for containerized high-level and low-level waste which would be delivered by truck or rail. Shafts would connect the receiving facilities to the mine for delivery of the containerized waste to transporter vehicles which would move the waste to its point of storage. In the case of the high-level waste, the canisters would.be lowered into a vertical hole in the floor of a room and the hole would be plugged for radiation protection. In the case of the low-level waste, the containers would be stacked for disposal.

Figure 5 shows the estimated land areas associated with the Federal Repository. The surface facilities would occupy approximately 100 acres and be the only visible evidence of the Repository. The excavation for a fullscale facility might occupy a land area with a radius of about one mile which would include 2,000 acres. Surface areas above the excavation, but outside the fence around the surface facilities, might be leased for general use. Surrounding the central excavated area would be an outer controlled area of approximately 16,000 acres in which mining operations and deep drilling would be controlled to avoid any compromise of the safe operation 
of the Repository. Surface areas over the outer controlled area would not be restricted from normal activities.

As pointed out in the objective, the general plan for the NWTS program calls for the eventual construction of facilities for terminal storage in various geologic formations at multiple locations in the United States. This approach incorporates a number of advantages into the program as shown in Figure 6. These include: (1) feasibility of a timely operation of a terminal storage facility is increased because of the simultaneous and parallel activities, (2) a retrievability concept for storage of waste becomes practical because other facilities are available to receive the waste should it be necessary to move it from one of the facilities for any reason, (3) it will make it possible for, more than one site to serve the country as a terminal storage facility so no one location need bear the burden for the entire United States, (4) reduced waste transportation costs are possible if more than one facility is used since they will be dispersed around the country, and (5) it el iminates concern regarding possible Federal Government reluctance to abandon possible sites after significant éxpenditure since other facilities will be available.

Although the sequence for developing a terminal storage facility may differ. slightly from one geologic formation to another, the generalized sequence can be characterized as having seven distinct steps as follows (also see Figure 7):

1. Identification of Formations of Interest

2. Reconnaissance Surveys

3. In Situ Tests

4. Area Studies

5. Detailed Confirmation Studies

6. Pilot Plant Operations

7. Conversion of the Pilot Plant into? a Federal Repository

These steps not only imply a scientific program but also a decision process. With respect to the latter, it is important to emphasize that it is the 
intent of OWI and ERDA to have an extensive series of reviews by federal, state and local organizations at appropriate decision points in the development sequence for each formation.

Although the review groups are still in the process of being established, it would be appropriate to indicate a few of them:

1. A long-term geologic integrity review group will be established, reporting to the Director of OWI, consisting of senior geologists, senior earth scientists, and other appropriate experts to review the entire geologic program on a continuing basis.

2. Basin or regional review groups will be created consisting of experts knowledgeable about the particular basin or region. The American Association of State Geologists has already been contacted regarding the establishment of these groups.

3. Federal-state review groups will be created consisting of representatives of agencies of the federal and state governments and other organizations who would have responsibility for or interest in some aspect of the NWTS program.

Another factor to be considered in the decision process is the environmental impact of a waste disposal facility. In order to understand how we expect to address this subject, I want to clarify certain terminology at the outset. In conformance with the National Environmental Policy Act of 1969 (NEPA), the AEC (now ERDA) established regulations contained in 10 CFR 11 which pertains to its own activities and conforms to NEPA. These regulations require that an environmental assessment be prepared for each significant federal action. Such an environmental assessment is an initial evaluation of the environmental impact of the project to be undertaken and serves as a decision-making document to determine if there may be a significant effect on the quality of the human environment. If such a determination is made, then the environmental assessment will be significantly expanded into an Environmental Impact Statement (EIS) which will be very broad and include items such as an in-depth treatment of alternatives and cost benefit analyses. 
In the NWTS program it is planned to go directly to a draft EIS for each. facility site without the environmental assessment. These draft EIS's will be circulated for comment by federal, state and local government agencies as well as the public. In addition, a public hearing or hearings on the draft EIS will also be convened when appropriate and in the public interest. Finally, the EIS will be issued and circulated with substantive comments attached.

Although the seven steps are distinct, it is not necessary that they all occur in sequence. For example, the in situ tests could proceed in parallel with other geologic studies.

Identification of Formations of Interest

In the process of identifying formations of interest, a review is made first which is based solely on the general knowledge of the geologic properties and/or fundamental properties of the rock type involved. If the review is promising, a reconnaissance survey would be undertaken. This step has already led to the identification of salt, argillaceous, crystalline rock and carbonate rock formations as formations of interest. However, others may also be identified in the future.

\section{Reconnaissance Survey}

The purpose of the reconnaissance survey would be to collect all the available data on those properties and characteristics of the formation needed for waste disposal considerations. This information provides a regional evaluation of the potential for utilization of the formation for waste disposal and may include (1) structure, stratigraphy, depth, and thickness; (2) hydrology; (3) mineralogy/petrology; (4) natural resources; and (5) general surface characteristics. Based upon the information compiled at this stage, the prospects for the formation are evaluated and reviewed and a number of smaller, perhaps "county size", regions are identified for further geologic area studies.

\section{In Situ Tests}

Once the formation is identified as a possible candidate for waste disposal, a set of in situ experiments will be conducted in parallel with other geologic studies ranging from simple electrical heaters placed in holes in 
exposed surface outcrops of the formation to extensively instrumented vault tests in excavations especially constructed at the expected depth of the pilot plant. In general, the vault tests are constructed to permit tests with both electric heaters and/or canisters of simulated waste which are removed at the conclusion of the experiment. They provide extensive information on the physical behavior of the rock, the waste canister, as well as the stability of the underground layout. In situ tests have already been completed for salt formations but still have to be completed for other formations of interest.

\section{Area Studies}

The geologic area studies that follow the reconnaissance survey are designed to develop new and specific data in the areas of interest. These studies include (1) core drilling at a density of perhaps 6 to 10 holes per 1,000 square miles to obtain adequate definition of the important subsurface characteristics of the formation, (2) field geologic mapping, (3) hydrologic studies, (4) geophysical surveys and (5) other geologic studies. It would be appropriate to note at this point that environmental assessments are usually required by each state in order to obtain drilling permits. In the NWTS program we will, of course, prepare an environmental assessment for each drilling operation. This is in compliance with ERDA regulations which conform to the National Environmental Policy Act of 1969. Upon completion of these studies, the suitability of the area is again reviewed and if it still appears promising, three or more specific locations will be identified for even more detailed confirmation investigations. There will be extensive reviews at this point involving all review groups that have been established. The selection by OWI and ERDA of specific locations for more detailed confirmation investigations and the final selection of pilot plant sites will be firmly based on all these reviews as well as public comments obtained during public progress reports.

Detailed Confirmation Studies

The detailed confirmation studies are directed toward specific locations of perhaps 2-5 square miles each. The investigations involve primarily the drilling and testing of four or more core holes at each location, plus 
the continuation of any specific geologic studies for which the previous results are inadequate to evaluate the suitability of the location. The results of this phase of the investigation would be to determine which locations fully qualify for consideration as pilot plant sites.

Pilot Plant Operations

After adequate review, a pilot plant site will be selected and a pilot plant constructed to evaluate the handling and storage operations using actual canisters of high-level waste and to confirm all design calculations. The initial pilot plant would consist of surface handling equipment and underground excavations which are portions of the full-scale facilities. Experiments would be performed to test retrievability devices, emplacement concepts, and, in general, evaluate the stability of the underground workings. The data obtained during the initial pilot plant operation would be used to design the expanded pilot plant which will be operated until it has successfully demonstrated that: (1) it can safely receive, emplace and store highlevel waste at the design rate, and (2) no anomalies in the geologic formation have been found.

\section{Conversion to Federal Repository}

The conversion of the facility to a Federal Repository will occur when sufficient data has been gathered to obtain the required licenses from NRC. This will be done at the earliest opportunity. When the facility is converted to a Federal Repository, the main change would be to drop the retrievability option and to backfill and seal the storage rooms.

At this point it is appropriate to briefly indicate the scope of the screening processes leading to the selection of pilot plant sites. This is graphically displayed in Figure 8. Although not specifically indicated, I want to emphasize again that all appropriate review groups will be involved in each step in the decision process.

Starting with the multiple geologic formations, we expect to identify a number of geologic study areas in each of the formations. The actual number will most certainly vary in each case and the total number will be much greater than the six shown. Within each study area it is then expected that a few detailed confirmation study locations will be identified. Not shown in the figure are the possibilities that no detailed confirmation 
study locations would be found in some study areas and many such locations may be found in others. From the wide selection of detailed study areas within many states, we then expect to proceed with the selection process leading to the identification of the six pilot plant sites required at various locations in the country. As you can see, there will be a large number of possibilities to choose from in the entire selection process. As a result of the efforts of the Oak Ridge National Laboratory over the last 15 years, considerable work on the first few steps in the general development sequence for geologic disposal has already been completed for salt formations. Still remaining are further reconnaissance surveys, area studies and the subsequent steps leading to an operating repository. A detailed planning schedule for the first two pilot plants is shown in Figure 9. What this planning schedule shows is a multiple phased study, design and construction schedule. I will only highlight certain aspects of it.at this time. The first phase shows identification of acceptable sites for. the first two pilot plants will not occur until the end of FY 1978. In the second phase, although purchase of 1 and and long lead items are shown, i.t. should be noted that land purchase will not start until the entire review process for site selection has been completed for salt formations. Phase 5 shows that hot operation of pilot plants 1 and 2 with actual radioactive waste will not occur until mid-1985 - almost nine years from the present time. The last phase shows safety studies and environmental studies contiruing lirough the whole pilot plant program.

It is now planned to construct six terminal storage facilities. The planning schedule for these facilities is shown in Figure 10. In that figure the solid triangle indicates the time area studies are started in the geologic formations of interest. Earlier work required for formations other than salt are not shown on this schedule.

As previously indicated, the first two pilot plants will be constructed in salt formations. The remaining pilot plants are expected to be constructed in other formations of interest. The startup for 'receiving waste for the first two plants is scheduled for the middle of 1985. The next. set. of twn 
facilities will start operations simultaneously two years later. The fifth and sixth:pilot plants will start at two-year intervals after the second set of two. Not shown on the figure is when the facilities will be converted to Federal Repositories. That will occur when the facilities are fully licensed by NRC.

At the present time there are a number of formations which are of interest in the NWTS program. Many of these are shown in Figures 11,12 and 13 . Figure 11 shows the rock salt formations in the USA. Of these, the Salina formation, the interior province of the Gulf Coast dome region, and the Paradox Basin are all considered to be formations of high potential for location of terminal storage facilities. Figure 12 shows the shale and clay formations in the USA, and Figure 13 shows the crystalline rock formations in the USA.

Considerable work has yet to be done in the formations other than salt since the reconnaissance surveys have not been completed in many cases and the in situ tests are yet to be started.

An important part of the OWI plan for the NWTS program is obtaining major support from organizations throughout the United States. The OWI is now in the process of developing a number of procurement packages which will lead to contract awards early in FY 1977. These packages are based on the NWTS program plan and on the response OWI received to the prospective participants conference held on May 11, 1976, in 0ak Ridge, Tennessee.

The plan for program support starting in FY 1977 follows this general plan:

a. A number of reconnaissance surveys will be initiated to review and document all available data on all formations of interest to the NWTS program.

b. Where previous reconnaissance surveys indicate the formation has potential for waste disposal, organizations will be designated as Geologic Project Managers (GPMs) with the responsibility of directing the geologic studies in the formation leading to the identification of candidate sites for location of pilot plants. Of course, the final 
selection process will be made with the assistance of the review groups indicated earlier.

c. An Environmental Project Manager (EPM) will be designated to prepare a thorough environmental study plan for all formations of interest. This plan will be prepared with the aid of environmental groups across the country. After preparation of the plans they will be distributed for general review and comment.

d. In formations where available information indicates that candidate sites are likely to be found, an Operations Project Manager (OPM) will be designated to take overail responsibility for all projects in the area. These responsibilities will include directing the efforts of the assigned GPM, assuring proper review and approval of final pilot plant sites, technically directing the efforts of Architect/Engineer design firms and construction firms, directing all safety analyses and environmental baseline studies as well as the preparation of the EIS, and, finally, operating the pilot plant should it be constructed.

e. Study contracts in the area of waste/rock interactions, nuclide migra-tion, rock mechanics, and borehole plugging will also be awarded. In the last case a demonstration of borehole plugging will be directed by a project manager designated for this purpose.

f. Several contracts will also be awarded in the area of engineering studies including in situ tests and design of special equipment.

g. The last items to be indicated here are a number of systems studies to be supported in areas such as waste canister envelope standards, economic analyses, transportation interface analysis, etc.

In this overview of the NWTS program, I have told you about our schedule fur six terminal storage facilities that will be located around the country - two in salt formations and four in other formations - and I have told you about the detailed development program and extensive review process leading to the establishment of safe operating facilities. This is a comprehensive program which plans for and indeed incorporates the participation and review at all major decision points of a large community of interested 
people and organizations as well as technical experts. This participation will occur through the review groups which include federal, state and local organizations, through the public review of the EIS at: each site, through the public review during the NRC licensing process and through. a large group of local and national contractors and consultants committed to creating the safe terminal waste storage facilities that are required by this nation. 
NWTS PROGRAM OBJECTIVE

TO PROVIDE FACILITIES IN VARIOUS DEEP GEOLOGIC FORMATIONS AT MULTIPLE LOCATIONS IN THE USA WHICH WILL SAFELY DISPOSE OF THE COMMERCIAL RADIOACTIVE WASTE WHICH MUST BE DELIVERED TO A FEDERAL REPOSITORY FOR TERMINAL STORAGE. 


\title{
10 CFR 50
}

LICENSING OF PRODUCTION AND UTILIZATION FACILITIES

\author{
APPENDIX F \\ SITING REPROCESSING PLANTS AND RELATED \\ WASTE MANAGEMENT FACILITIES
}

- high-level liquid radioactive waste (HLLRW) is WASte FROM THE FIRST SOLVENT EXTRACTION CYCLE.

- hLLRW CAN be Stored for maximum of five years.

- HLLRW SHALL be CONVERTED tO DRY SOLID PLACED IN SEALED CONTAINER PRIOR TO TRANSFER TO FEDERAL REPOSITORY. ,

- h.l. waste shall be stored no longer than 10 years.

OWI-76-21

Figure 2 


\section{CFR 20}

STANDARDS FOR PROTECTION AGAINST RADIATION

PROPOSED CHANGES INCLUDE

TRANSURANIC WASTE DISPOSAL

- tRU WASTE is WASTE CONTAMINATED WITH LEVELS

AS LOW AS 10 NANOCURIES OF TRANSURANIC ELEMENTS PER GRAM OF WASTE.

- tRANSFERRED tO ERDA STORAGE WITHIN 5 YEARS AFTER GENERATION. 


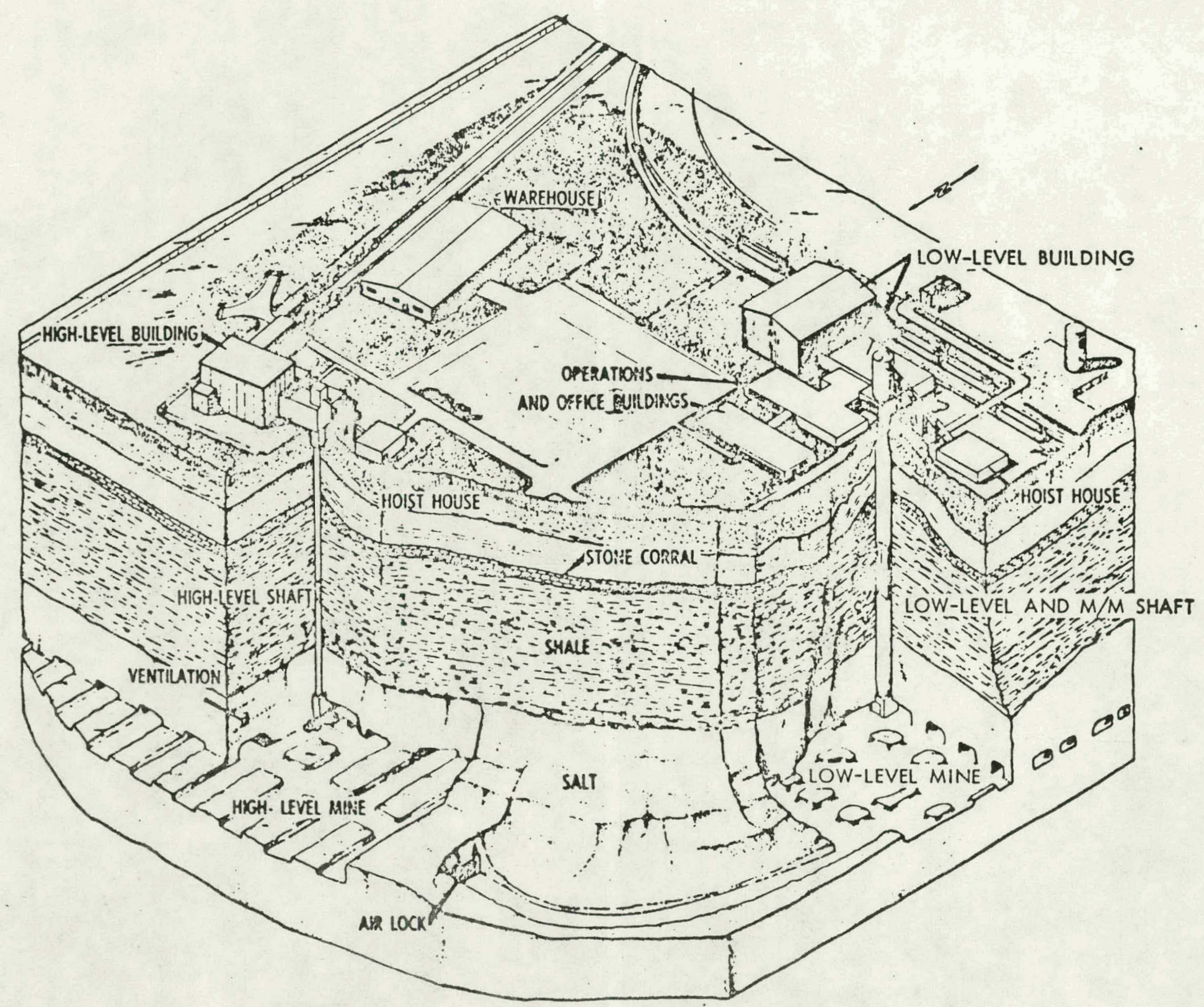

ARTIST'S CONCEPT FEDERAL REPOSITORY 


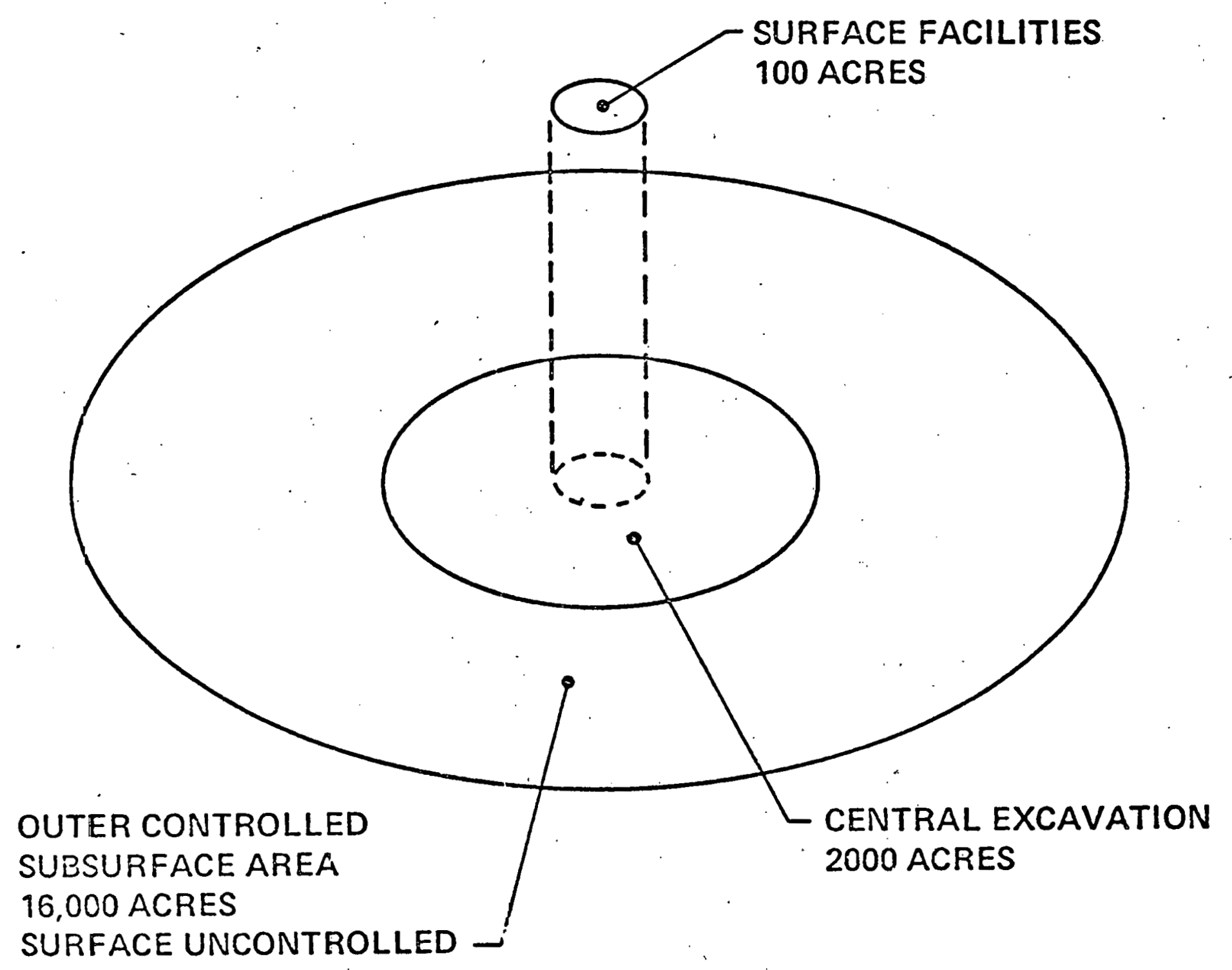


NWTS MULTIPLE SITE APPROACH

- FEASIBILITY OF A TIMELY OPERATION OF A TERMINAL STOPAGE FACILITY IMPPOVED BECAUSE OF SIMULTANEOUS AND PAPALLEL ACTIVITIES

- PERMITS RETRIEVABILITY CONCEPT

- WILL MAKE IT POSSIBLE FOR MOFE THAN ONE SITE TO SERVE THE COUNTRY AS A TERMINAL STORAGE FACILITY

- REDUCES TRANSPORTATION COST IF MORE THAN ONE IS USED

- ELIMINATES CONCERN REGARDING POSSIBLE FEDERAL GOVERRMENT RELUCTARCE TO AEANDON POSSIBLE SITE AFTER SIGNIFICANT EXPENDITURE 
GENERAL NWTS DEVELOPMENT SEQUENCE

1. IDENTIFICATION OF FORMIATIONS OF INTEREST

2. 2. RECONNAISSANCE SURVEYS .

3. IN SITU TESTS

4. AREA STUDIES

5. DETAILED CONFIRMATION STUDIES

6. PILOT PLANT OPERATIONS

7. CONVERSSION OF THE PILOT PLANT INTO A FEDERAL REPOSITORY 
SITE SELECTION PROCESS
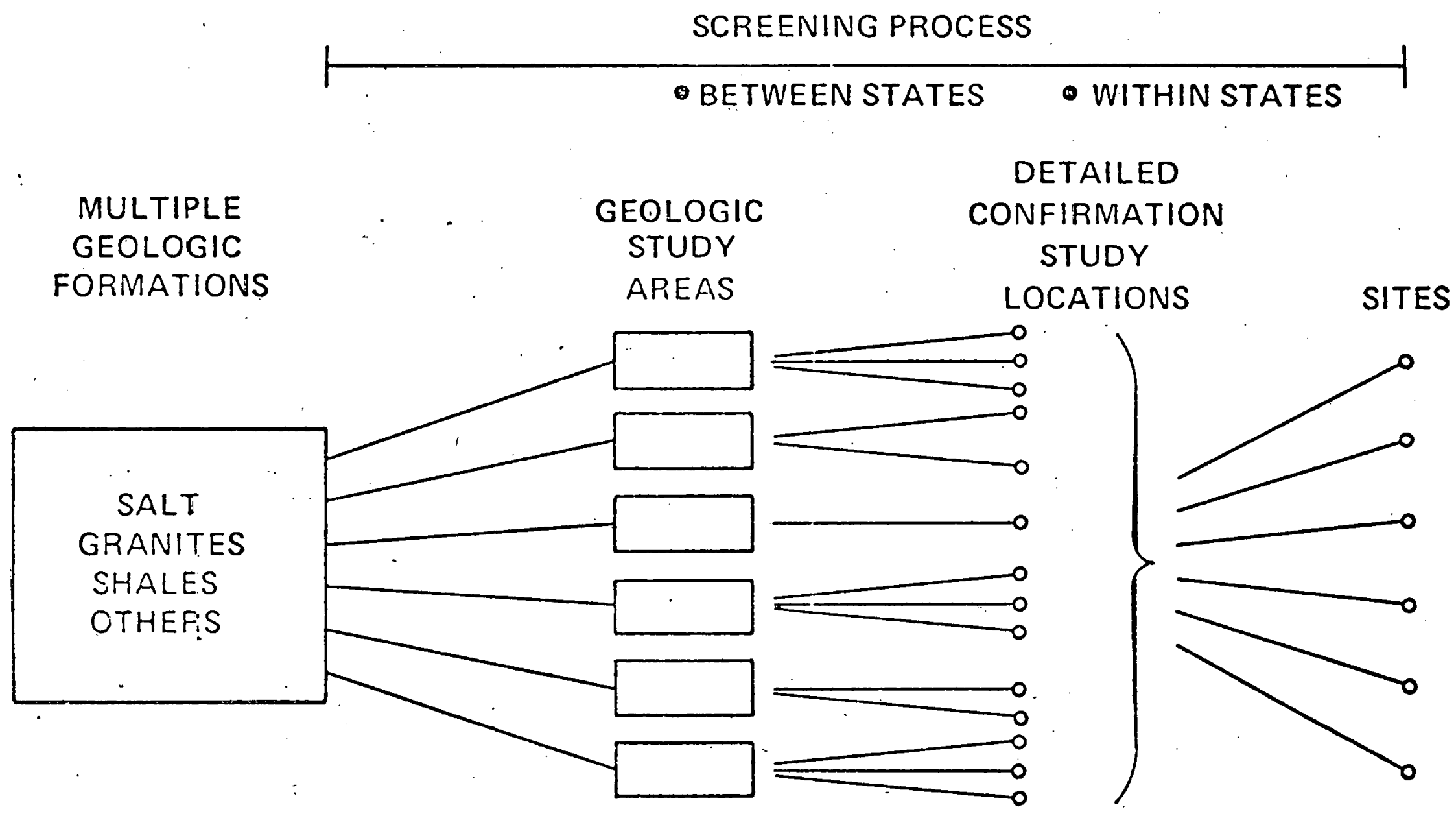
GEOLCGIC TERMINAL STORAGE

PILOT PLANT NO. I CESIGN AND CONSTRUCTION SCHEDULE

Pilor Plan! Fecsibility Srudies

1. Pilot Plent Site Selection

2. Preliminery Desian Studios

Lond Acquj is irion ond Long Load lrems

1. Congressional

Review end Acpicuol

2. Purchase Lond and Procure Long. Leod liems

Pilop Piont Dosign

1. Congressional Reviow orid Approval

2. Tirle I and Partial Title II

Pilop Plont Construction

1. Congrossionol

Review and Approval

2. Complete Title II, Construction and Tillo

3. Cold Testing

Pilop Plant Hot Operation

Sofety and Environmontal Studies

1. Sofoly Studies

2. Environmental Studies

a. Regional Study Plans

b. Regionc! Base Line Study

c. Site Specific Base Line Study

\begin{tabular}{|l|l|l|l|l|l|l|l|l|l|l|l|l|}
\hline & $F Y-77$ & $F Y-78$ & $F Y-79$ & $F Y-80$ & $F Y-81$ & $F Y-82$ & $F Y-83$ & $F Y-84$ & $F Y-85$ & $F Y-8 C$ & $F Y-87$ & $F Y-28$ \\
\hline
\end{tabular}

$\Delta$

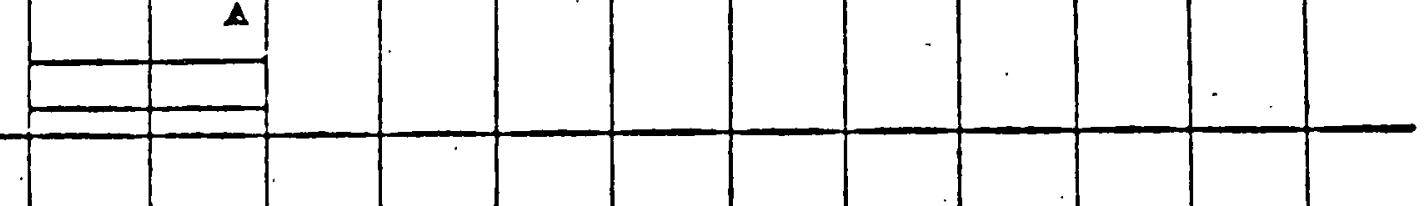

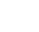


GEOLOGIC TERMINAL STORAGE

GENERAL PLAN

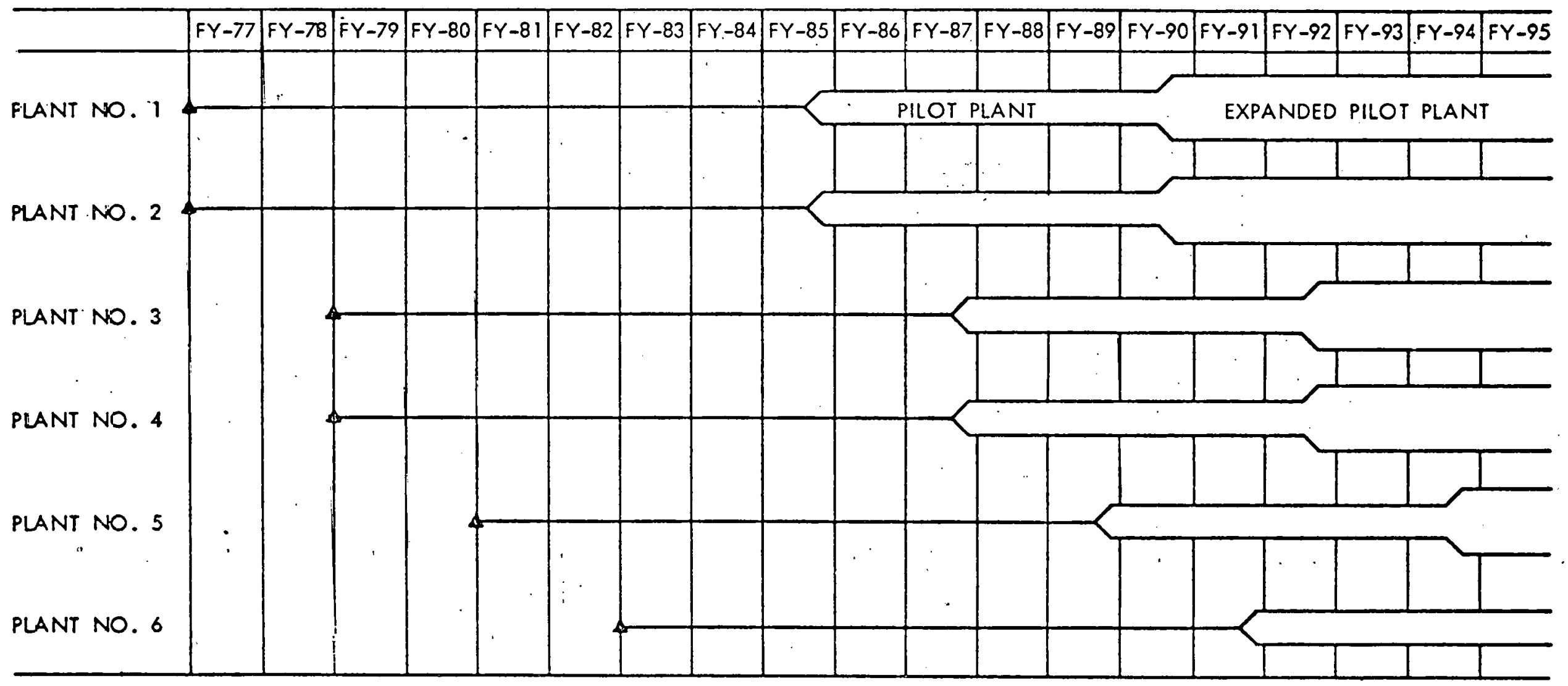




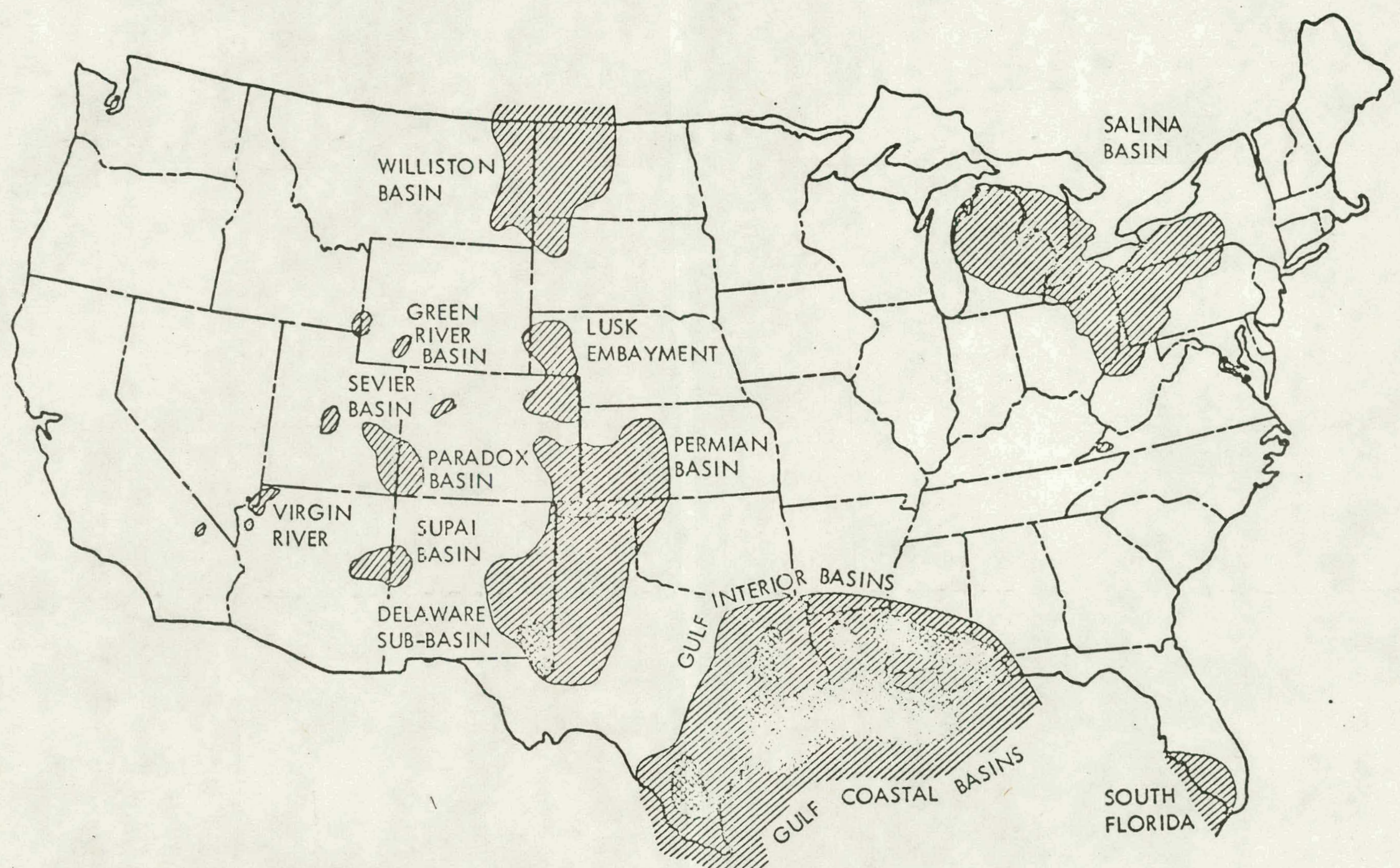

ROCK SALT DEPOSITS IN THE UNITED STATES

(AFTER PIERCE AND RICH, U.S.G.S. BULL. 1148) 


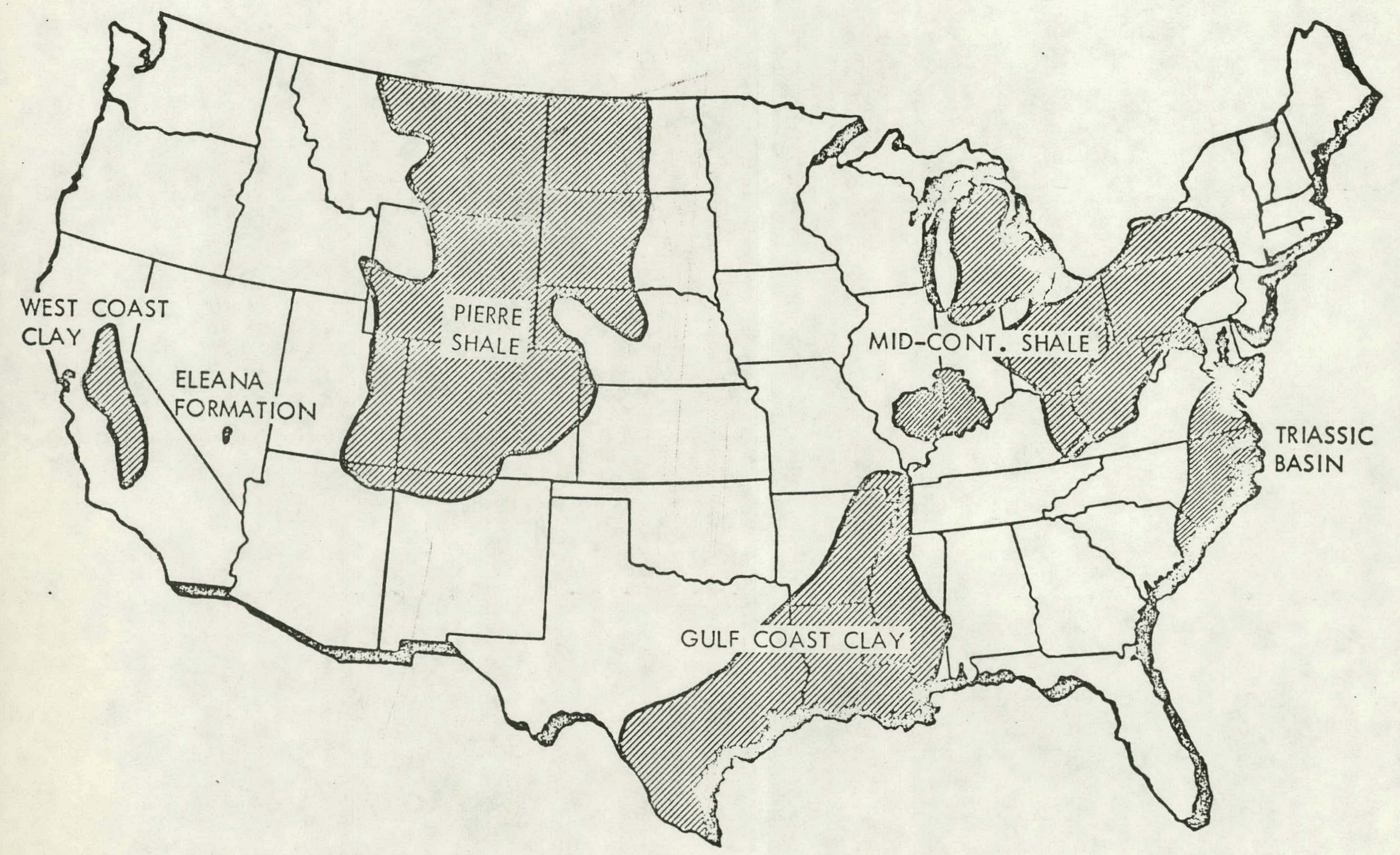

ARGILLACEOUS FORMATIONS IN UNITED STATES 


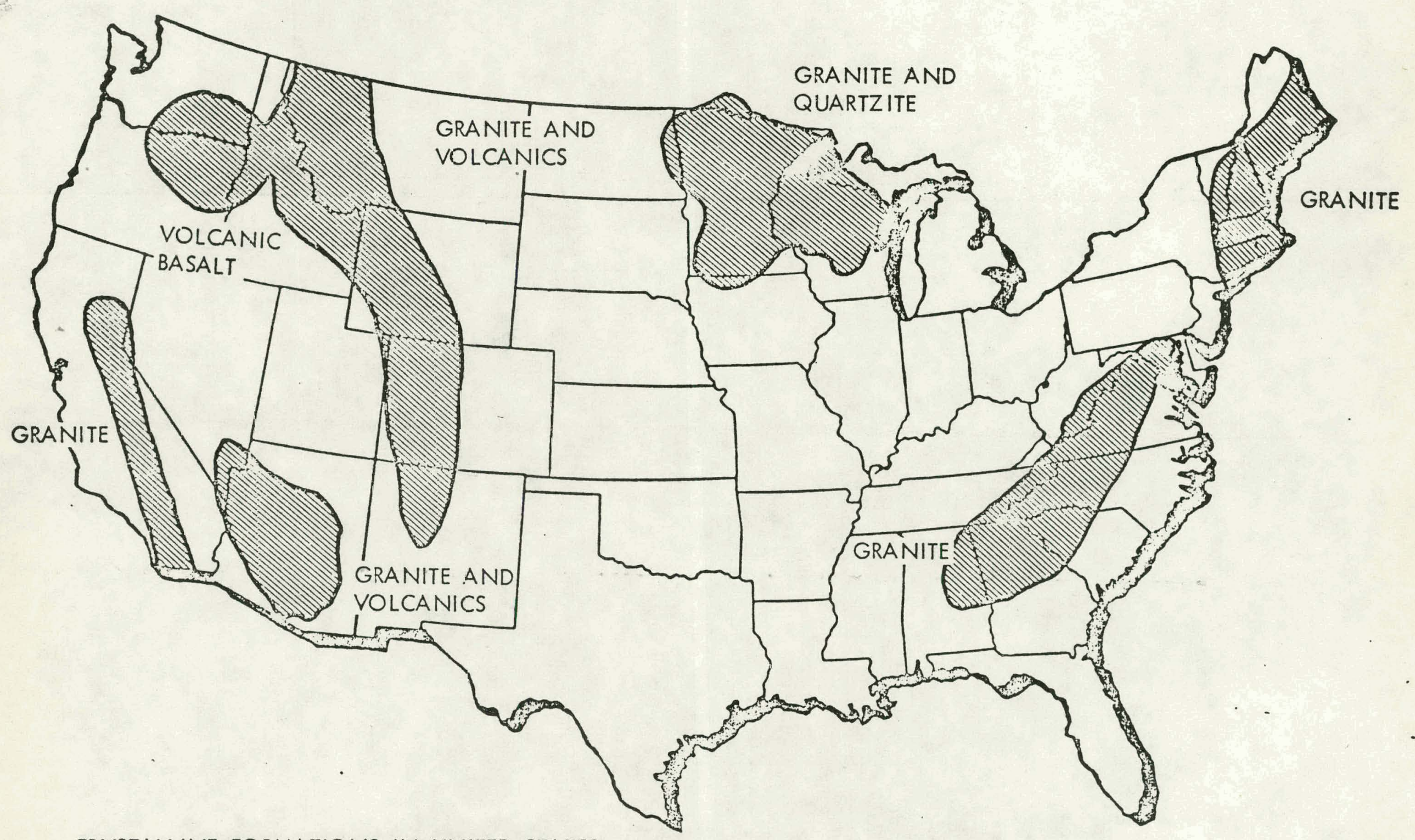

CRYSTALLINE FORMATIONS IN UNITED STATES 
BACKGROUND AND REVIEW OF

INVESTIGATIONS IN THE. SAL INA SALT BASIN

William C. McClain

Presented to the

Michigan Environmental Review Board July 26, 1976

The previous papers have provided an overview of the nuclear fuel cycle and the nationwide program to establish geologic waste disposal facilities. In this presentation, I would like to get more specific and describe our interest in the Salina Salt Basin. Perhaps the most convenient way to begin is to retrace the salient historical points of the previous investigations on the use of natural salt depcsits for the disposal of radioactive waste.

\section{History of Salt Studies}

Very early in the program for the development of commercial nuclear power, it was realized that the ultimate disposal of radioactive fission products, the ashes of the nuclear reactions, was one of the problems that must be solved if the promise of nuclear power was to be fulfilled. Accordingly, in 1955, a committee of the National Academy of Sciences/ National Research Council, consisting of earth scientists and nuclear engineers was convened at the request of the $A E C$ to consider possible solutions to this problem. This committee concluded that deep burial in geologic structures offered the most promising solution of the options considered and of the several formations considered, natural salt 
deposits were identified as the most promising geologic environment for this purpose. The particularly advantageous properties of salt which led this committee to this recommendation were:

1. Salt is widely abundant. It underlies portions of 23 states and is by no means considered a highly valuable natural resource.

2. Salt has a relatively high thermal conductivity (compared to other rocks) which heips to limit the maximum tenperatures. resulting from the heat generating wastes. It also has radiation shielding properties approximately equivalent to concrete.

3. Salt is easily mined. Salt mining is one of the most efficient underground extractive industries and is supported by a well developed technology.

4. Perhaps the most important advantage is that salt formations are totally isolated from and impermeable to circulating water. One of the mechanisms for preserving this impermeability is the ductility of plasticity of salt. This property allows a salt formation to deform very easily without fracturing and tends to heal any fractures which might develop.

Salt is, of course, not without disadvantages. The principal disadvantages are:

1. Salt is very soluble in water compared with other rocks. This means that whercver and whenever it is exposed to circulating. water, it is very rapidly removed. 
2. Salt is deposited by evaporation of sea water in closed sedimentary basins. Since sedimentary basins are also the depositional environment for hydrocarbons, $0 i 1$ and gas is frequently found in association with salt formations. Both of these disadvantages can be avoided by careful site selection. Following the NAS recommendation of natural salt deposits for the disposal of radioactive wastes ${ }^{1}$, the Oak Ridge National Laboratory embarked upon an experimental program aimed at developing suitable concepts and demonstrating their feasibility. The most important test in this series was conducted in the mid-60s at the Lyons, Kansas mine and was called Project Salt Vault. In this experiment, irradiated fuel elements from the Engineering Test Reactor at Idaho Falls were used (augmented by electrical resistance heaters) to simulate the radiation and heat generation properties of solidified high-level waste. Over the 18-month course of the experiment, over 3.5 million curies of activity were transported into (and out of) the mine, successfully demonstrating the feasibility of remotely handling intensely radioactive materials in an underground environment. This experiment also provided a wealth of datd un the in situ and full scale physical and mechanical properties of salt under the influence of elevated temperatures, temperature gradients, radiation fields, and overburden stresses.

During this same period, a number of broad, geological surveys of the several salt formations in the country were undertaken (including the Salina Salt Basin) as the first steps in the evaluation of their suitability for waste disposal. ${ }^{2,3,4}$ Copies of these documents have been provided to MERB and the Governor's Task Force. 
Following the analysis of the Project Salt Vault data and a number of other design studies, the AEC in june 1970 announced its intention of establishing a Federal waste repository adjacent to and encompassing the inactive Lyons mine provided that subsequent geological investigations confirmed the suitability of that site. Those investigations over the next t::o years resulted in the conclusion that the Lyons site was, in fact, not suitable. However, it is interesting to note that the factors which disqualified this proposed site were related entirely to man's activities (a high density of oil and gas exploration holes in the immediate vicinity and a nearby solution mining operation) and not to the natural geologic conditions, and certainly not due to any fundamental question of the utility of salt formations in general for this purpose. In 1972 , a series of reconnaissance surveys was undertaken to identify potential alternative areas and salt deposits which might be suitable for a repository. These surveys included: 5

1. The central Kansas portion of the Permian Basin. These investigations were carried out largely by the Kansas Geological Survcy and progressed to the point of drilling three exploration core holes.

2. The Delaware Basin portion of the Permian Basin in New Mexico.

3. The Gulf Coast Salt Dome. Province.

4. The Paradox Basin salt structures in Southeastern Utah.

5. The Williston Basin salt in Montana:

6. The Supai Basin and Luke salt deposit in Arizona, and

7. The Salina Salt Basin underlying several northeastern and north central states (I will return to this later). 
Most of these reconnaissance surveys were carried out by the U.S. Geological survey. Based upon the results obtained from these surveys, attention was redirected to the Carlsbad area of New Mexico and detailed confirmation studies on a prospective site there are still in progress directed at creating a Waste. Isolation Pilot Plant for storage of ERDA waste. Further work in the other sait formations was temporarily suspended when the Carsbad study was started.

\section{Requirements for Geologic Disposal}

I would like now to digress briefly and discuss some of the broader issues relating to geologic disposal and in this way, to illustrate the rationale behind the current interest in the Salina Salt Basin. First, I would like to point: out that there are other alternatives to waste disposal in excavations in deep continental formations. These include:

1. Emplacement in holes in the seabed. ,

2. Emplacement in continental ice sheets, especially Antarctica.

3. Separation of the very long-lived actinide fraction and the separate elimination of it by either transmutation in nuclear reactors or rocketing it off the earth (into solar orbit or solar impact).

All of these alternatives, although philosophically attractive, are beyond the present state of technology and would require extended development programs. On the other hand, emplacement in excavated underground openings is well within the present state of technology and, for the case 
of salt formations, has been demonstrated. in the proof-of-principle experiment - Project Salt Vault. It therefore remains the alternative of preferred choice at the present time although research is continuing on the other concepts.

The requirements for ultimate disposal of radioactive wastes can be simply stated as the complete and total isolation of the nuclides from man's environment for the duration of their hazardous lifetime. For geologic disposal, monitoring and surveillance after sealing the under-. ground excavations would be carried out but the longevity of the wastes implies that the continued containment of the wastes should not depend upon those functions or any other active control measures by man.

For geologic disposal this general requirement can be interpreted in the following way: The particular formation and geologic structure must (1) isolate the waste materials from any contact with circulating groundwater, and (2) be sufficiently stable and removed from ordinary geologic processes that isolation will be maintained. For disposal in salt formations, these general requirements translate to the following suitability guidelines:

1. Minimum depth should be several hundred feet in order to remove both the formation and the waste from any ordinary surficial process such as glacial action or erosion.

2. Maximum depth is limited to approximately $3000 \mathrm{ft}$ because of the natural tendency of the mine to deform rapidly at higher overburden pressures (i.e., greater depths) due to creep. 
3. The minimum thickness of the salt formation should be about $200 \mathrm{ft}$ in order to take full advantage of its thermal and mechanical (plastic) properties.

4. Topographic relief of the area should be relatively low so erosional processes do not represent a threat to the containment.

5. The salt formation must be isolated from the active hydrologic regime and even from permeable formations having a potential for circulating water given a drastic change in the climatological conditions.

6. The formation should be located in a stable interior region not subjected to active structural processes.

7. The salt formation should not be associated with any scarce natural resource which night be attractive to future generations. Now, with that background, I would like to return to the main theme of this presentation. The Salina Salt formation which extends through the Michigan and Appalachian Basins (shown in Figure 1) is often referred to as the Salina Salt Basin. It is one of the great salt deposits of the country. Consequently, it was considered as a possible alternative to the central Kansas area in 1972 along with the other salt formations mentioned earlier. In this case, Dr. K. K.'Landes of the University of Michigan, a world renowned evaporite geologist and specialist on the Salina Salt was asked, to review the entire formation and evaluate $i$ ts prospects for waste disposal. ${ }^{6}$ Landes concluded that portions of the Appalachian Basin might be suitahle, hut concentrated his investigations 
on the Michigan Basin. The Silurian age (over 300 million years old) salt formations are deposited in a flat, nearly circular, bowl-shaped bas in almost entirely covering the lower peninsula of Michigan. The salt is both thicker (Fig. 2) and deeper (Fig. 3) at the center of the basin and becomes thinner and shallower as one approaches the edge of the basin. Application of the depth limits alone restricts the usable portions of the Michigan Basin to a zone around the outer edges, especially the southeast and northeast quadrants. These two areas were examined by Landes in some detail in 1972. His approach in this examination was to describe and compare nine specific locations; four in the southeast area, five in the northeast (Fig. 4). Based upon this study, Landes. concluded that both areas offered prospects of meeting geological requirements but that considerable further work would be required. This is especially true for the northeast area where very little subsurface data is available on the salts. By contrast, the geologic character of the salt formations in the southeast quadrant'are much better defined as a consequence of exploration activities primarily associated with the extensive salt extraction industry there.

As I mentioned earlier, following the reconnaissance surveys in all of the major sal.t basins, the ERDA geologic disposal program effort was limited to investigations of the southeast New Mexico salt deposit and all other activities were suspended. Beginning in mid-1975, the program was enlarged in a way which eventually lead to the establishment of the Office of Waste Isolation described earlier. The objectives of this enlarged.program included the identification and certification of a number of potential sites for geologic waste disposal. This enlarged 
program rekindled the interest in the Salina Salt Basin as a whole and Ken Landes was again asked to participate. Specifically, he was requested to update his earlier work and identify four study areas in the Michigan Basin and four study areas in the Appalachian Basin which would be suitable for further more detailed investigation. Unfortunately, he was unable to undertake such a broad program at that time but did reexamine the prospects in northeastern Michigan. 8 I might add that, at about the same time, a study was initiated with Netherland, Sewell and Associates - a petroleum engineering and geological consulting firm in Dallas, Texas for an evaluation of the hydrocarbon potential of the entire Salina Salt Basin. ${ }^{7}$ Landes' approach to his updating study was, again, to describe, and compare seven specific Jocations, all in the northeast quadrant of the lower peninsula. These seven locations are shown also on Fig. 4. The results of this study were discussed with other consultants and with the Michigan Geological Survey. In general, it was concluded that a large area of northeastern Michigan, comprising Alpena County and portions of Presque Isle and Montmorency Counties was appropriate as a geologic study area. It was also concluded that there are undoubtedly several other similarly sized areas in both the Michigan Basin and the Appalachian Basin which would similarly qualify as geologic study areas. .. It is perhaps interesting at this point to review the map showing depth to the salt (Fig. 3) and to superimpose the nil and gas analysis map (Fig. 5) from the Netherland, Sewell study. These two factors effectively define the boundaries of the geologic study area of interest in northeastern Michigan as well as identify other potential study areas. 
Study Area Investigations

As described in an earlier presentation, after the completion of a reconnaissance survey and the identification of a geologic study area, the next phase is a more thorough examination of that study area. These investigations would consist of: (1) geophysical surveys, (2) air-photo and remote sensing analysis, (3) field geologic mapping, (4) special studies such as analys is of dissolution processes in the area, and (5) a multi-hole program of subsurface exploration by core drilling. Core drilling is an absolutely essential component of any geologic study area investigation because it provides:

1. Detailed stratigraphic log of the formations, especially the salt formations, to a scale. which is not possible with electricalmechanical instruments. Also, specimens from the core would be subjected to extensive laboratory analys is for mineralogical constituents, moisture content, and a broad range of physical properties.

2. Detailed information on the nature and properties of overlying, underlying, and interbedded non-salt formations (especially hydrologic properties by in-hole testing) which are particularly important in the evaluation of the suitability of the salt.

3. The precise depth and thickness of the several salt beds apparently available in the area, and the changes in these parameters over the area - i.e., detailed structure and thickness contour maps of the type shown earlier for the entire basin but at a much larger scale. 
One approach to the subsurface investigations in the northeast Michigan area (which was developed by consultants to OWI) is illustrated by the tentative eight-hole drilling program shown on Fig. 6. In this particular case, the investagatory strategy was to drill a relatively large diameter hole from bedrock to total depth, with a full suite of wireline geophysical logs (for future correlations), extensive down-hole hydrologic testing of any aquifers encountered and elaborate precautions against data losses from encountering unexpected conditions. The optimum location for this type of first test hole is the center of Alpena County - a location almost exactly in the center of the study area and over 10 miles from the nearest existing hole. The locations of subsequent holes in this program would then be adjusted based upon the information obtained and their scope and objectives would be reduced; for example, by taking a smaller diameter core; coring only in the salt formation or even selected beds within the salt formation, and undertaking a less extensive hydrologic testing program. Of course, other strategies are equaliy valid if the geologic character of the area is to be equally well understood at the completion of the investigations. For example, the first hole could be drilled at some other location with limited objectives, such as testing the edge of the rapidly thinning salt section (see Fig. 2) at a location where relatively nearby existing wells would provide guidance on the conditions likely to be encountered and directly correlatable depth and thickness data.

In this way, the alternative drilling strategy would start with relatively inexpensive drilled holes to confirm the geologic character of the formation near its edge and then use this data to extrapolate into regions 
where little data is available and where more expensive cored holes need to be located and drilled. 


\section{References}

1. Hess, Harry H., et al., The Disposal of Radioactive Waste on Land: Report of the Committee on Waste Disposal of the Division of Earth Sciences, National Academy of Sciences - National Research CounciT, Publication 519 (April 1957).

2. Pierce, W. G. and E. I. Rich, Summary of Rock Salt Deposits in the United States as Possible Storage Sites for Radioactive Waste Materials, Geological Survey Bulletin 1148, United States Government Printing office, Washington : 1962.

3. Galley, John E. et al., Radioactive Waste-Disposal Potentials in Selected Geologic Basins - A Reconnaissance Study, SAN-413-2 (June 24, 1964).

4. Galley, John E. (ed.), Subsurface Disposal in Geologic Basins - A Study of Reservoir Strata, Memoir 10, The American Association of Petroleum Geologists, TuTsa, Oklahoma, U.S.A., 1968.

5. Staff of the ORNL Pilot Plant Repository Project, Alternative Geologic Formations for the Disposal of Radioactive listes, ORNL - CF - .72-6-42, (June 30, 1972).

6. Landes, Kenneth K., Possible Salt Mine Sites for Radioactive Waste Disposal in the Northeastern States, (June 30, 1972).

7. Netherland, Sewell \& Associates, Inc., Preliminary Regional Study of the Present and Possible Future $0 i 1$ and Gas Development in the Areas of Thick Rock Salt and Shale Lejosits of Michigan, Ohio, Pennsylvania, and Wes tern New York as of December, 1975, (December 1975).

8. Landes, Kenneth K., Possible Salt Mine and Brined Cavity Sites for Radioactive Waste Disposal in the Northeastern Southern Peninsula of Michigan, SC 7010, (May 31, 1976). 


\section{SALT DEPOSITS IN STUDY AREAS}

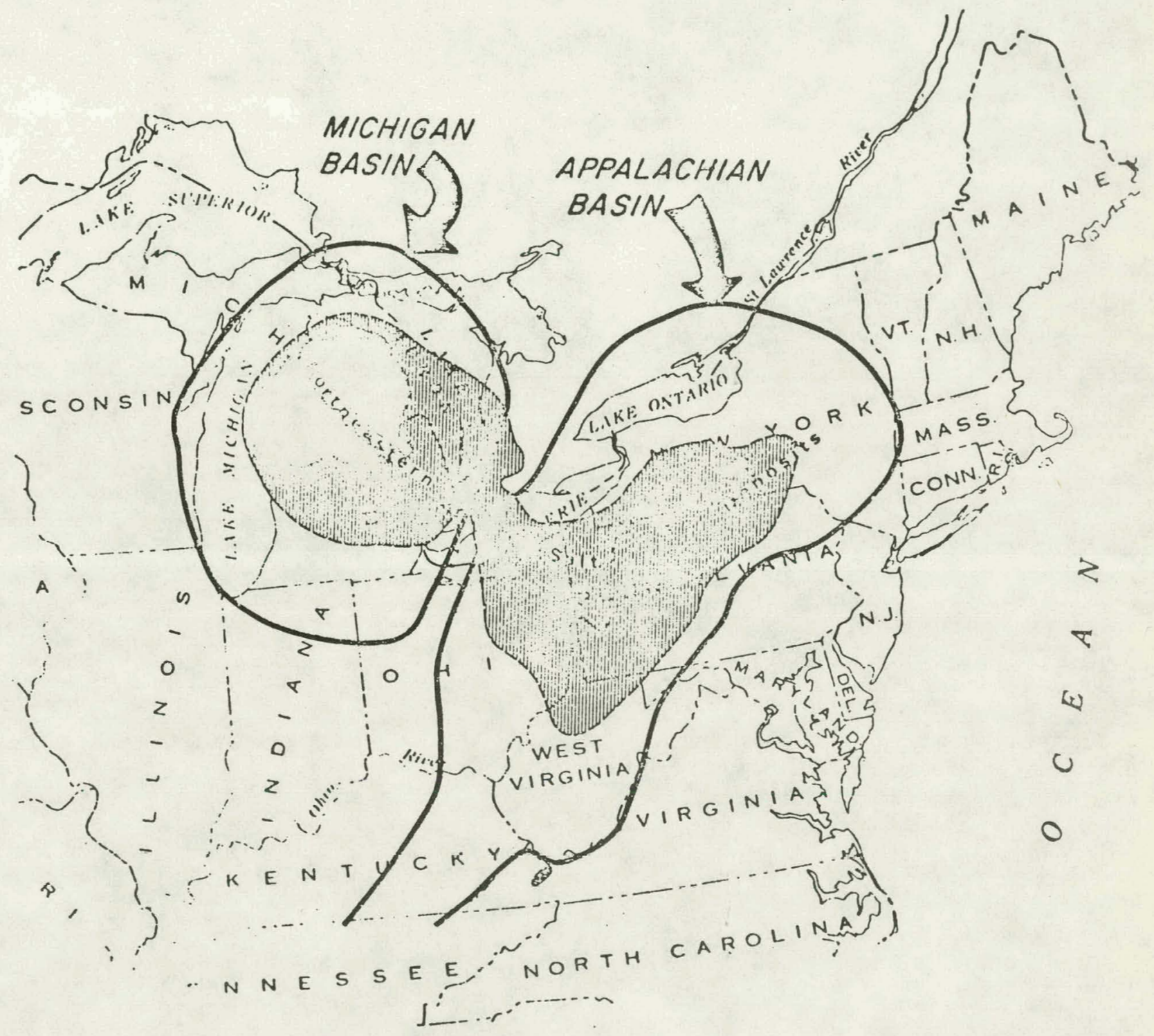

NETHERLAND, SEWELL \& ASSOCIATES, INC. DALLAS, TEXAS DECEMBER, 1975

FIGURE 1 


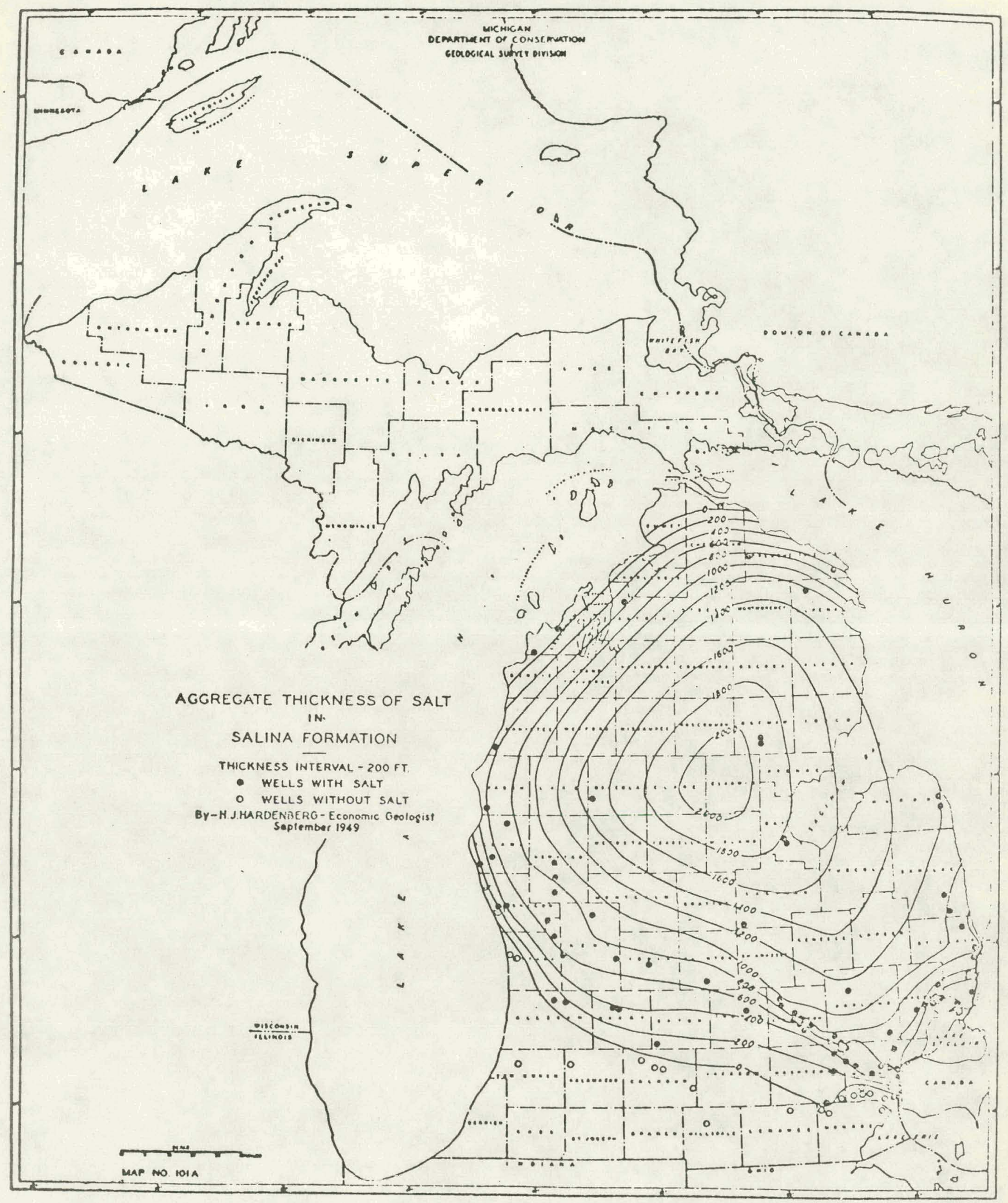

FIGURE 2

ow1 $76-106$ 


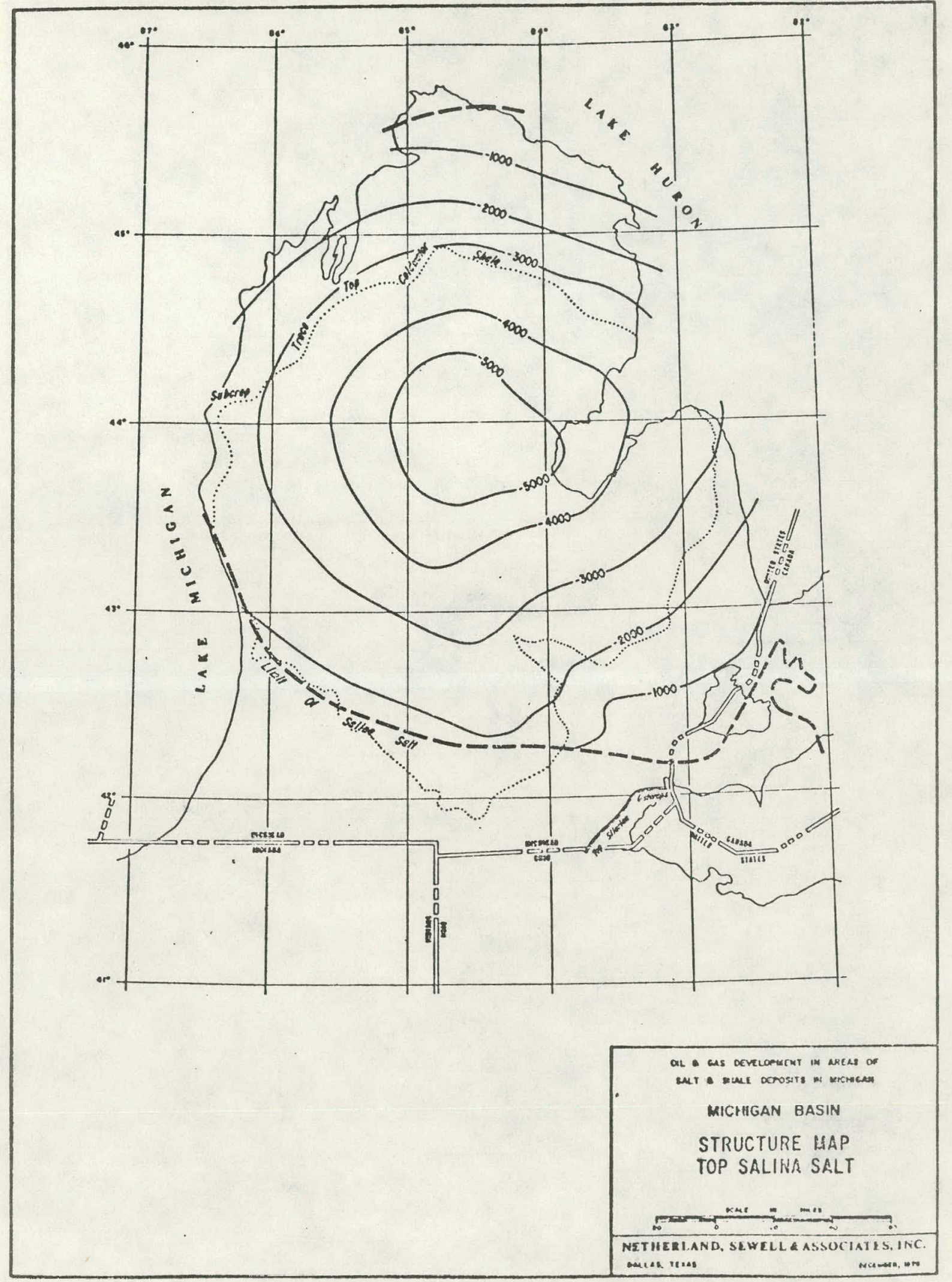

FIGIIRF 3 


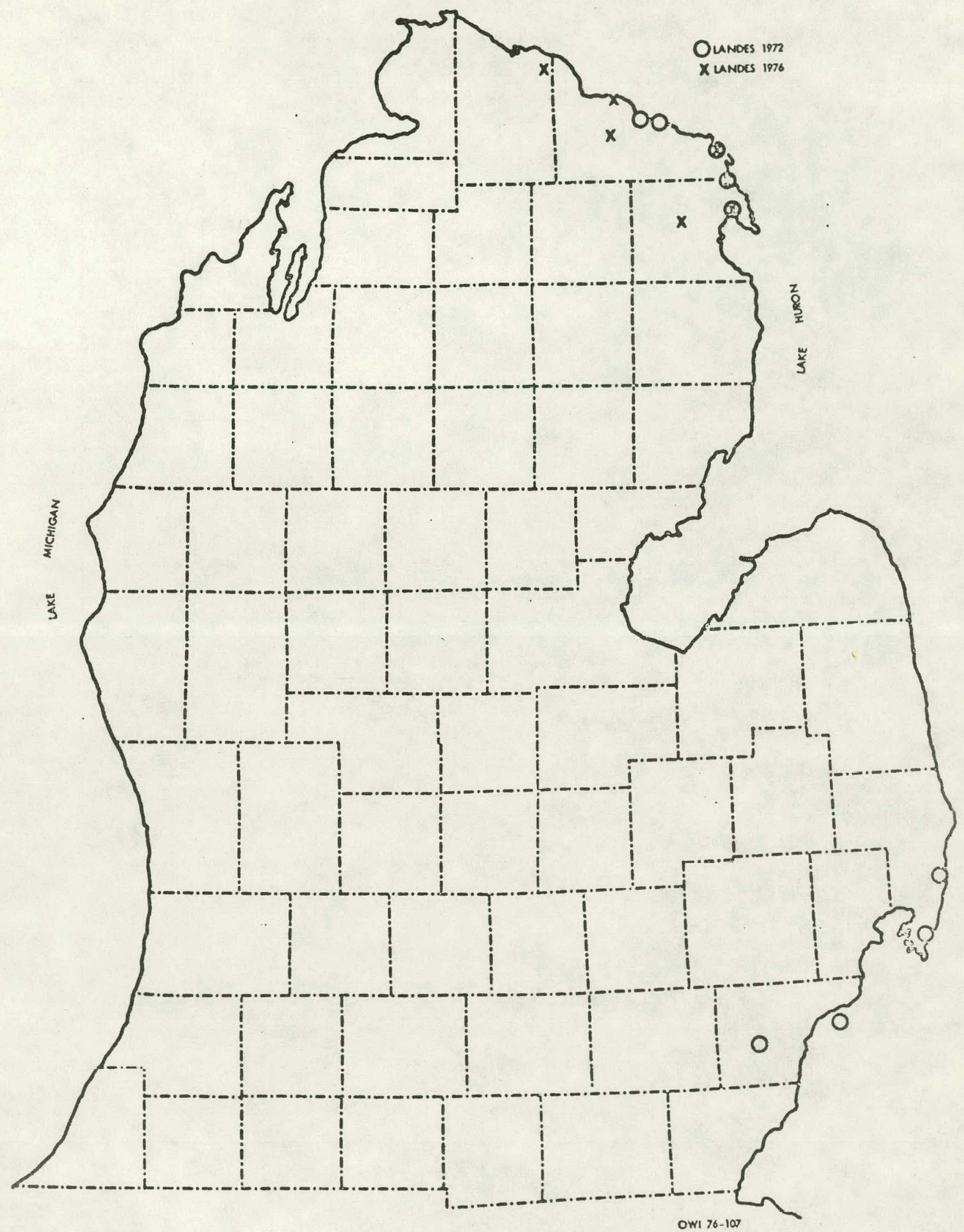

FIGURE 4 


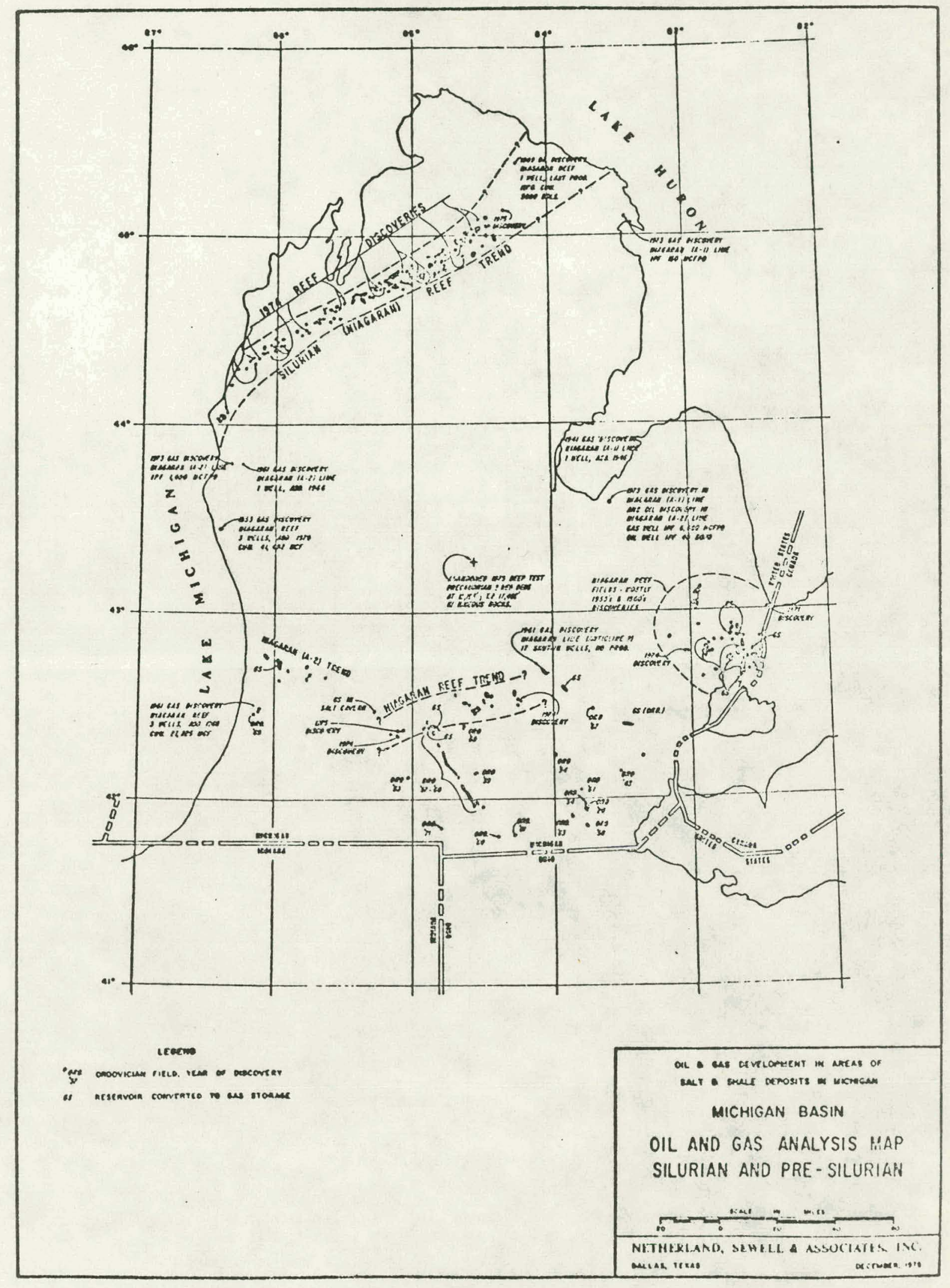

FIGURE 5 


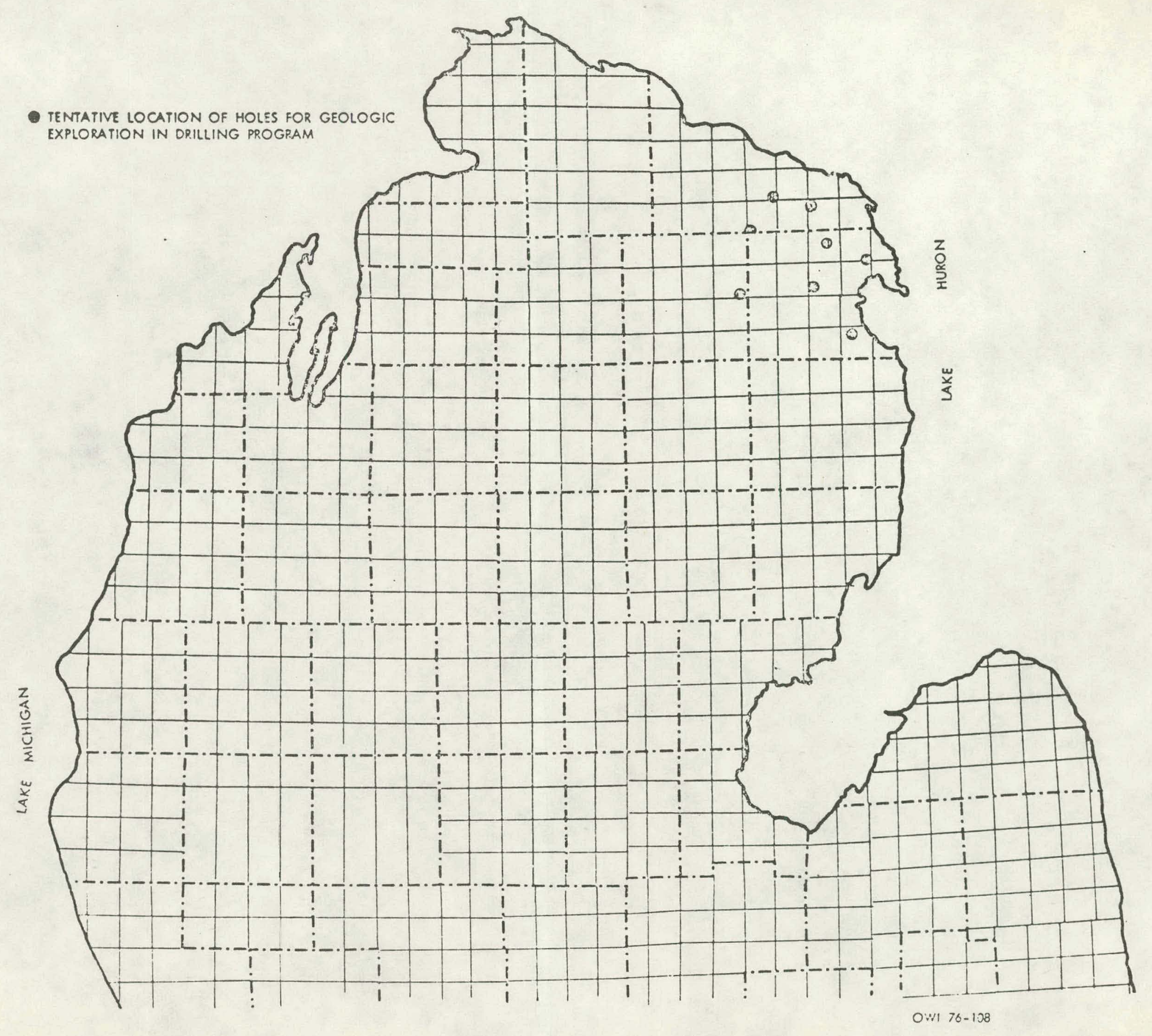

FIGURE 6 
Alex F. Perge

ROLE OF TRANSPORTATION IN THE NUCLEAR FUEL CYCLE

The schematic diagram 18 another graphic portrayal of the nuclear fuel cycle and is helpful for visualizing the role of transportation in the nuclear fuel cycle of near-term Industrial interest, namely the 11ght water reactor of approximately 1,000 MWe capacity. Every arrow on the diagram represents a transportation step. These steps currently involve both truck and rail shipment. The weight values shown are indicative of the quantity of material to be transported per year for a typical reactor. Note that, as the material progresses through the cycle it becomes increasingly concentrated, that 1s, the amount of material becomes less and less. I should also point out that, in general, as material progresses through the cycle, the ruggedness of packaging is increased. Radioactivity of the material is very low up to the point of undergoing fission in the reactor. However, after irradiation of the fuel in the reactor the radioactivity requires that the fuel be shielded for all subsequent handling and transportation operations. The heaviest or most dense shielding materials are the most desirable.

Another point I would like to touch on, by way of introductory remarks, is that it is the thickness of shielding material that is important. A given thickness of lead, steel, or depleted uranium is essentially just as effective in shielding elght fuel assemblies as one assembly. This fact leads to a very important point as regards handling and transportation, namely that the weight to be handled depends primarily on the thickness of shield required, and to a very much lesser extent on the weight of payload. 


\section{Description of Transportation Steps in the Fuel Cycle}

\section{A. Mining to Milling - Ore}

Ore Is usually sand or limestone rock and is shipped from the mine to the miling plant. Ore is classified as low specific activity material. It is transported in bulk by truck or rail. Approximately 27.2 MT of ore 18 transported per vehfcle. Since the milling plant Is generally located in close proximity to the mine, the distances involved are about five mfles and in general do not involve public highway. Where ore shipments are trucked from remote mine locations, haulage could involve transport over public highways.

\section{B. Milling to UF 6 Production}

The mill product is a powder and ranges in consistency from granular to powder. This powder, commonly called "yellowcake," Is shipped from uranium milling plants in the western United States to two sites in the United States as well as abroad for conversion to $\mathrm{UF}_{6}$.

Under the regulations of the DOT, the mill product is classified as low specific activity material.

Typically, the concentrate is packaged in 55-gallon steel drums

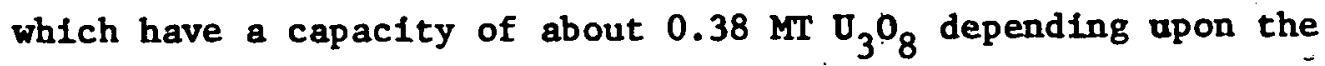
moisture content of the concentrate. For truck shipments, approximately 40 drums are loaded per vehicle. This results in a net weight of about $15.2 \mathrm{MT}$ of $\mathrm{U}_{3} \mathrm{O}_{8}$. For rail shipments, approximately 100 drums are loaded on one car, or a net weight of 
about $38 \mathrm{MT}$ of $\mathrm{U}_{3} \mathrm{O}_{8}$. In some cases as many as 160 to 180 drums are loaded in one car by using deck boards on top of the first layer of drums and putting a second layer on top. All shipments are likely to be made under exclusive - full-load - arrangements. Such shipments are transported an average distance of 1,000 miles.

The average transit time is five to six days by truck and seven to ten days by rall. Shipments may also be made by truck and rail, 1.e., by truck to a rail head and then by rail to the conversion plant.

C. UF ${ }_{6}$ Production to Isotopic Enrichment Plant - Natural UF 6 . $\mathrm{UF}_{6}$ is a white solid at room temperature. At higher temperatures, It melts to form a clear, colorless, high-density liquid. Natural $U_{6}{ }_{6}$ shipped as a solld from the UF 6 production plant to a gaseous diffusion plant for lsotopic enrichment.

Under the regulations of the DOT, $\mathrm{UF}_{6}$ is classified as low specific activity material.

Typically, UF 6 is packaged in a 10-ton cylinder. Almost all shipments of $\mathrm{UF}_{6}$ are made by truck. Normally, one 14-ton cylinder is loaded per vehtcle or two 10-ton cylinders per vehicle. All shipments are likely to be made under exclusive use - full-1oad - arrangements. Such shfpments are transported an average distance of 500 miles. 
Shipments of slightly enriched and depleted $\mathrm{UF}_{6}$ may also be made among the three gaseous diffusion plants on an exclusive-use basis, and $U_{6}$ may be shipped from the fuel reprocessing to the enrichment plants.

Time in transit varles from 8 hours to 2 days, with an average of 11 hours.

D. Enrichment Plant to UO 2 Plant - Enriched UF 6

Enriched $U_{6}$ is a flssionable material and does not differ in appearance from the natural $\mathrm{UF}_{6}$. It is shipped as a solid from the gaseous diffusion plant to the fuei fabrication plant (or the $\mathrm{UO}_{2}$ production plant).

Under the regulations of the NRC and DOT, enriched UF 6 is shipped as Type $A$, fissile material.

Typically, enriched $\mathrm{UF}_{6}$ is packaged in 2-1/2-ton cylinders. Nomally, shipments are made by truck. Truck shipments will likely be made under exclusive use - full-1oad - arrangements. Such shipments will be transported an average distance of 750 miles. Five (5) cylinders constitute a full load.

Time in transit varles from 6 hours to 7 days, with the average shipment taking $1-1 / 2$ days. 
E. $\mathrm{DO}_{2}$ Plant to Fuel Fabrication - Enriched $\mathrm{OO}_{2}$ $\mathrm{UO}_{2}$ is produced from $\mathrm{UF}_{6}$ as a powder. It 18 compacted to form pellets for loading 1nto fuel tubes. Fuel fabrication plants may receive the $\mathrm{UF}_{6}$, and convert it to $\mathrm{DO}_{2}$ prior to other processing, In which case there will be no transport of $\mathrm{DO}_{2}$. In other cases, a fuel fabricator may recelve $\mathrm{UO}_{2}$ elther as powder or pellets from a conversion facility.

Under the regulations of the NRC and DOT, $\mathrm{UO}_{2}$ is shipped as Type $A$, fissile material.

Typically, $\mathrm{UO}_{2}$ is packaged in steel palls, within an inner gasketed steel cylinder which is supported in a double high 55-gallon steel drum. Approximately $0.11 \mathrm{MI}$ of $\mathrm{UO}_{2} 18$ packaged per drum.

Almost all shipments of $\mathrm{vO}_{2}$ are made by truck. Normally, 40 drums are loaded per vehicle, with a net weight of $4.5 \mathrm{MT}$ of $\mathrm{UO}_{2}$ per shipment. Shipments will likely be made under exclusive use - full-load arrangements. Such shipments w1ll be transported an average distance of 750 miles.

The time in transit varies from a few hours to 10 days, the average shipment being 3 days.

\section{F. Fuel Fabrication P1ant to Reactor - Fabricated Fuel As8emblies}

Fresh fuel in the form of uranium dioxide pellets in a zircalloy rod is welded shut at both ends to form a fuel rod. A fuel assembly 
18 made up of 50 (for BWR) or 200 (for PWR) rods about 13-1/2 feet long. A BWR fuel assembly containing $200 \mathrm{~kg}$ uranium would typically welgh about 550 pounds; a PWR fuel assembly containing $500 \mathrm{~kg}$ uranium would typlcally weigh about 1500 pounds.

Almost all shipments of fresh fuel are made by truck. About six truckloads of fuel elements are shipped to a reactor each year. Each shipment will travel a distance of 1,000 miles on the average (a :minimum distance of 25 miles to a maximum of 3,000 miles).

Under the regulations of NRC and DOT, fresh fuel is shipped as flssile Class II material (number of packages per shipment limited by transport index per package to assure criticality control). It Is essentlally non-radloactive and requires no shielding. Time in transit can vary from a few hours to 10 days.

G. Transportation of Irradiated Spent Fuel

Spent fuel assemblies are intensely radioactive and continue to generate "decay" heat. Many flssion products have short half-lives. Therefore, the spent fuel is placed in a cooling basin at the reactor site in order to allow the shorter-lived radioactive fission products to decay. Thereafter, the spent fuel 18 shipped to the reprocessing plant in heavy lead, steel, or depleted uranium shlelded shipping casks whlch range from 20 to 100 tons in welght. 
Spent fuel transportation is unusual in that the loaded casks weigh from 20 to 50 times as much as the product being shipped. Cask capacities will vary from about 5 metric tons of uranium for a 100-ton (railroad) cask to about $4 / 10$ metric ton of uranium for a 20-ton cask. Use of larger cask s1zes and rail shlpment, where feasible, reduces the total cask miles traveled, total transit time and the handling time for loading and unloading casks - since these factors are determined by the number of cask loads (shipments) far more than the amount of product shipped per caskload.:

Spent fuel cask shipments can be made by truck, rafl or barge. Legal we1ght trucks can transport casks welghing about 25 tons. The use of overweight trucks requires state highway department approved opecial overwelght operating permits for each state traversed.

Rall casks can range from 20 to 100 tons, but are typically in the 50 to 75 ton range. Whereas the typical truck shipment might haul 1 to 2 PWR fuel assemblies per load, a typical rall car shipment might haul 8 to 10 , at a gross weight level well within accepted limits for the "road."

Barge shipments are a distinct possibllity where sultable waterways are avallable. In such a case, gross cask weights of up to 125 tons have been considered. However, this mode of transportation is not yet in commercial use. 
Reactor plants in the near term will be located throughout the eastern and mid-western United States from Florida to Maine, from Minnesota to Texas and down along the west coast states of Washington, Oregon, California (and perhaps Arizona). Reprocessing plants with the potential for near-term operation are in West Valley, New York, and Barnwell, South Carolina. Thus, the spent fuel transportation network spans the continent, with the heaviest concentrations in the eastern half. Shipping distances range from hundreds to thousands of miles.

In general, a typical reactor power station might originate in the range of 6 to 10 spent fuel shipments per year if by rail, or in the range of 60 shlpments per year if by truck.

A reprocessing plant of the Allied-General Barawell capacity (1500

- metric tons urantum per year) might recelve 300 to 500 shipments per year if by rall or 3,000 shipments per year if by truck.

H. Transportation of Low-Leve1 Waste

Low-level wastes are generaced at the UF 6 production planto, fuel fabrication plants, and fuel reprocessing plants which may be shipped offitte for disposal.

In the case of $\mathrm{UF}_{6}$ production plants, this waste, with a volume of about $8,000^{3} \mathrm{ft}$., consists of hydrofluor ash, paper, raga, gloves, tools, etc. contaminated with uranium. It 1s normally 
packaged in sealed 55-gailon steel drums and shlpped by common carrier to comercial land burlal facilities as low specific activity radioactive material. Th1s 18 equivalent to 1,100 to 1,600 drums or 20 to 30 trailer loads per model LWR annual fuel requirement.

In the case of fuel fabrication plants, approximately $5,000^{3} \mathrm{ft}$. of waste, consisting of paper, rags, gloves, tools, etc. Is shipped in sealed 55-gallon ateel drums by common carrier to commercial land burlal facilities. This is equivalent to 700 to 1,000 drums or 15 to 20 trafler loads per model LWR annual fuel requirement.

In the case of the fuel reprocessing plants, approximately $1,000^{3} \mathrm{ft}$. of waste, conslsting of laboratory waste, amall tools, gloves, . clothtng, resins, etc. is shipped in sealed 55-gallon steel drums by common carrier to commercial land burial facilities. This is equivalent to 150 to 400 drums or 3 to 8 traller loads per model LWR annual fuel requj rement.

Low-level wastes from $U_{6}$ production, fuel fabrication, and fuel reprocessing are shlpped under the regulations of the Department of Transportation. Time in transit varies from 8 hours to 2 days, with an average of 11 hours.

I. Fuel Reprocessing Plant to Federal Storage Factlity - High-Level Wastes The solidified fission product waste from fuel reprocessing plants must be shipped for long-term storage in the ultimate site for 
high-level waste storage no later than 10 years following separation of the fission products from the irradiated fuel. At that time, the decay heat of the fission products will be less than five percent of the level present when the spent fuel was originally recelved from the reactor.

For the near-term, it 18 assumed that solid wastes will be retained at the reprocessing plant site for essentially the full ten-year perlod. Following this perlod, they will be shipped by rall to the Federal repository.

Shippling containers will resemble the casks utilized in shlpments of spent fuel from the reactor the reprocessing plant. A shipment is assumed to consist of approximately 10 to 12 waste containers. The shipment will contain roughly 10 megacuries of radioactivity in about $100^{3} \mathrm{ft}$. of solid waste from a fuel requirement of a model LWR, and generate approximately 29 kilowatts. Such shipments will be transported an average distance of 2,000 miles and will take, on the average, approxtmately 8 days. 


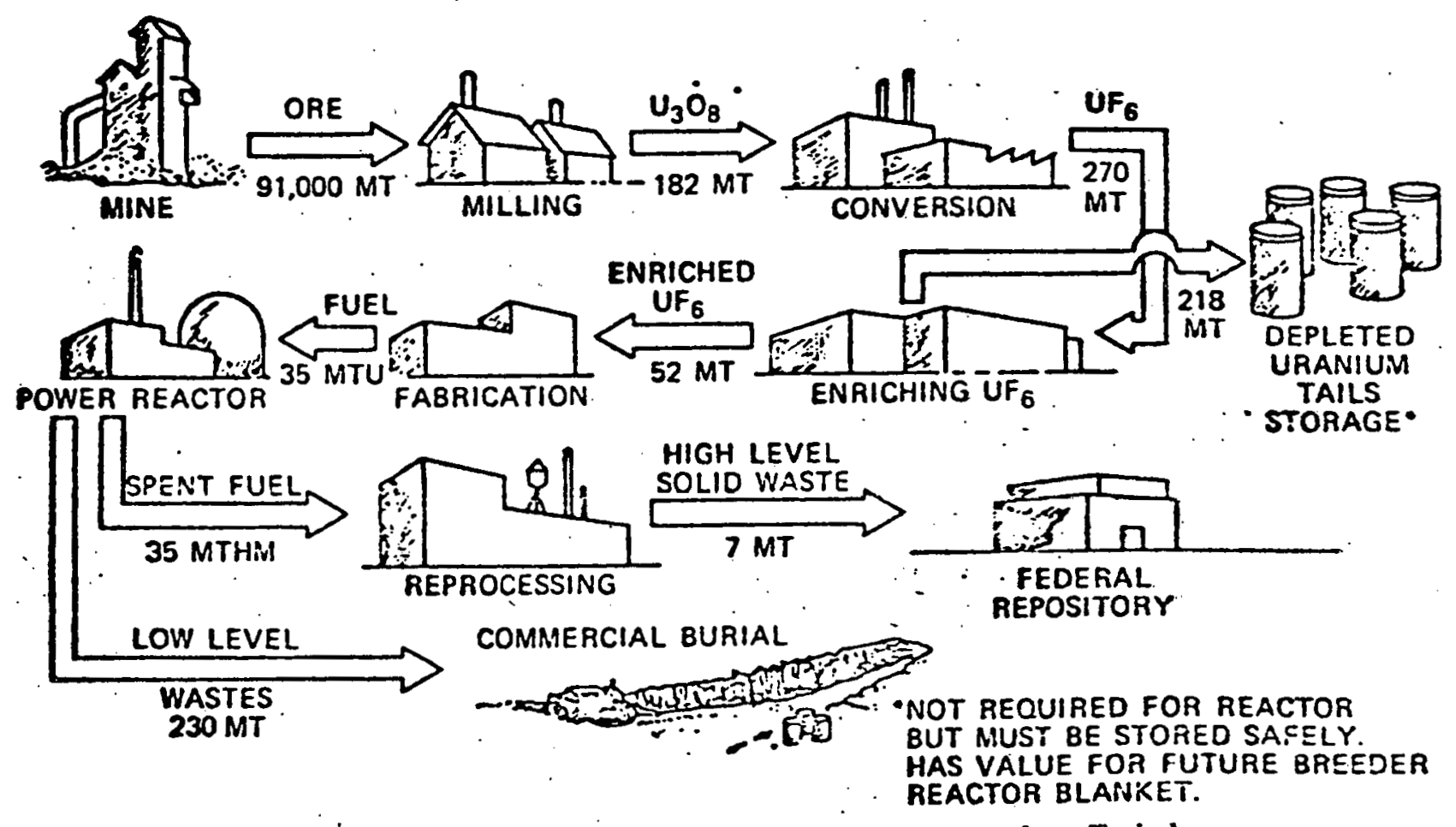

Average Annual Fuel Materials Requirements for a Typical 1000 Mive Light Water Reactor 


Uranium ore
Uranium ore concentrates
Normal UFE
Enriched UFB
Enriched uranium oxide powder
or pellets
New fabrieated fuel assemblie?
Low level radioactive wastes
Irradiated fuel
Uranyl nitrate
Plutonium oxide

Fission product radioisotopes

High level radioactive solis wastes

MATERIAL FLOW IN THE NLCLEAR FUEL CYCLE

. Polse to polst moveeneats

Uranium mines to uranium mills

Uranium mill to feed preparation plant

Feed preparation plant to enriching (gaseous diffusion) plant

Enriching plant to materials processing and/or fuel fabrication plant

Materials processing plant to fuel fabrication plant

Fuel fabrication plant to nuclear power reactors

All facilities to commercial burial sites

Nuclear power reactor to chemical reprocessing plan

Chemical reprocessing plant to fuel fabrication plant or to UFe feed preparation plant

Chemical reprocessing plant to fuel fabrication plant

Chemical reprocessing plant to Government or industry users

Chemical reprocessing plant to Federal repository

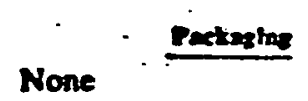

Droms

Pressurized cylinders

$\because$

Pressurized cylinders and protective packages

Drums and birdcages with prolective packags

Special fuel element shipping contsiners

Drums and shielded protection packages

Shielded casks

Tank trucks. tank cars and protective packiges

Protective paclages and special plutonium containers

Shielded casks

Shielded easts 


\title{
SPECIAL TECHNICAL ISSUES
}

\author{
Presented to the \\ Michigan Environmental Review Board \\ July 26,1976
}

I would like now to respond to several specific technical questions which frequently arise in discussions of the disposal of radioactive wastes in natural salt deposits. The answers to these questions are based primarily upon the analysis of the proposed repository at Lyons, Kansas (and other information). Although the details may change sligritly because of differences in the characteristics of the salt formation and possible differences in the facility design, I think that these answers will provide a reasonably accurate description of various effects.

\section{Waste Quantities and Characteristics}

Estimates of the quantities of the various classes of wastes generated were recently presented by Blomeke and Kee (at the Denver Symposium) based upon the "Low Growth" of commercial nuclear power case projected by ERDA in February, 1975. This case projects 70GW(e) of installed nuclear generating capacity in 1980 growing to $625 \mathrm{GW}(\mathrm{e})$ in 2000. The estimates are also based on the assumption that commercial fuel reprocessing comnences in 1978. 
High-level wastes are composites of all the liquid waste streams arising from reprocessing of spent fuel. They contain more than $99.9 \%$ nonvolatile fission products, $0.5 \%$ of the of the/plutonium and uranium and all of the other actinides formed by the nuclear reactions in the fuel. In their solidified final form $\left(3 \mathrm{ft}^{3}\right.$ per ton of fuel) and after 10 years of interim storage, the total volume accumulates according to the schedule: $40 \mathrm{~m}^{3}$ in 1988, $280 \mathrm{~m}^{3}$ in $1990,1300 \mathrm{~m}^{3}$ in $1995,3210 \mathrm{~m}^{3}$ in 2000 and $10,750 \mathrm{~m}^{3}$ in 2010. Present regulations require delivery of this material to a Federal repository at 10 years of age but permit delivery at any earlier time. We visualize that the solidified high-level waste will be packaged in cylindrical canisters not exceeding 12 inches in diameter and 10 feet long $\left(6.25 \mathrm{ft}^{3}\right)$. The characteristics of a single waste canister depend upon its size, solidified form of the waste, and its age, but a typical range would be a heat generation rate of $2-5 \mathrm{~kW} /$ canister and a radioactivity of 0.5 1.0 MCi/canister. Both heat generation and radioactivity, decay with a half-life which is initially about 30 years.

Cladding wastes consist of the solid fragments of Zircaloy and staintess steel fuel cladding and other structural components remaining after the core has been dissolved. In addition to neutron-induced radioactivity, the cladding wastes contain about $0.05 \%$ of both the non-volatile fission products and actinides in the spent fuel. If these wastes are compacted to $70 \%$ of their theoretical density, the volumes produced are approximately the same as for high-level wastes. Because of the contained radioactivity, cladding wastes will require shielding similar to that for 
high-level wastes. Therefore, we anticipate that this category of waste will be delivered in the same type of canister and will be handled in the same way using the same equipment. However, it should be emphasized that the heat generation rate of the cladding wastes is $1-2 \%$ that of the high-level wastes.

Transuranium wastes is defined as those solid or solidified materials that contain plutonium or other long-lived alpha emitters in known or suspected concentrations greater than $10 \mu \mathrm{Ci} / \mathrm{g}$. A small fraction of these wastes will have sufficiently low external radiation levels after packaging that they can be handled directly. A much larger fraction will be sufficiently contaminated with fission products to produce surface dose rates between 10 and $100 \mathrm{millirems/hr}$ after packaging, probably in 55-gal. drums or standard-sized boxes. It is estimated that these wastes will be. generated at a rate of approximately $283 \mathrm{~m}^{3}\left(10,000 \mathrm{ft}^{3}\right)$ per ton of fuel reprocessed or total accumulated volumes of: $300 \mathrm{~m}^{3}$ in $1983,9200 \mathrm{~m}^{3}$ in $1990,27,900 \mathrm{~m}^{3}$ in 2000.

Low-level waste is composed of those diverse materials that are contaminated with low levels of beta- and ganma-emitting isotopes, but contain less than $10 \mu \mathrm{Ci} / \mathrm{gm}$ of long-lived alpha activity. For a closed fuel cycle, they will be generated at a total rate of about $2000 \mathrm{~m}^{3} /$ ton of fuel reprocessed. (measured after volune reduction processing). It is assumed that these wastes will be shipped to commercial surface burial grounds as is the present practice. 
There are also several other types of waste generated at fuel reprocessing plants (Noble gases, fission-product iodine, and tritium) for which the decisions on processing, packaging, storage, and disposal have not yet been made. However, the volumes of these wastes and their handling problems are quite small compared to any of the other classes of waste. 


\section{Temperature Effects on Salt}

Elevated temperatures increase the plasticity of salt, resulting in accelerated rates of creep (time dependent) deformation. This accelerated creep is identical in nature to that produced by increased overburden stresses and therefore can be accomodated in the design of the underground openings.

If the salt contains moisture in the form of small $(0.1-1.0 \mathrm{~mm})$ brine inclusions in amounts greater than about $0.5 \%$ by volume (a fairly typical value), small unconfined specimens will violently decrepitate at temperatures between $250^{\circ}$ and $300^{\circ} \mathrm{c}$. That is, it explodes due to the pressure of the steam in the small trapped inclusions in much the same way that popcorn "puffs". There is no evidence that confined salt (as it would be in situ in a waste repository) decrepitates in this way, even at temperatures of several hundred degrees celcius, and certainly not at the desian temperatures for a waste repository.

These small brine inclusions also respond to thermal gradients because of the difference in the solubility of salt in water at the very slightly different temperatures on opposite sides of the inclusion. This difference causes a single phase (all brine) inclusion to migrate up the thermal gradient (i.e. toward a heat source) while two phase inclusions migrate much more rapidly down the thermal gradient (i.e. away from the heat source). Migration of brine inclusions away from the waste is, of course, no consequence. Brine inclusions which migrate toward the waste canister will either become trapped against the hole liner or, if the waste is separated from the solid salt by an annular space, will break 
out into that space, flash to steam and be carried off in the mine ventilation air. Calculations of this phenomena suggest that for a salt formation containing $0.5 \%$ water by volume, each high-level waste canister will produce a total of 20-30 liters of water from brine migration effect at a maximum rate of 2-3 liters per year. All of this water is produced within the first 20-25 years. Thereafter, brine migration ceases because the thermal gradients have become so flat they can no longer drive the system. 


\section{Temperatures - Thermal History}

The maximum temperatures reached at any particular point in the salt formation and the time after waste burial at which that maximum occurs is a complex function of the heat generation rate of the canisters, their age at burial and the spacing between adjacent canisters. For salt, rigorous temperature limits have been established of: (1) only a tiny volume of salt immediately adjacent to (within a couple of inches) the waste canister is allowed to exceed $250^{\circ} \mathrm{C}$ and only a fraction of the salt making up the disposal horizon is allowed to exceed $200^{\circ} \mathrm{C}$. Using these limits, it appears that the maximum heat output of any single canister will be about $7 \mathrm{~kW}$ and that the maximum areal power density in a high-level waste repository should not exceed about $150 \mathrm{kW/}$ acre. At the mine level, the peak temperatures of $175-200^{\circ} \mathrm{c}$ occur approximately 50 years after emplacement of the waste. These peak temperatures decline to about $130^{\circ} \mathrm{C}$ at 150 years and $100^{\circ} \mathrm{C}$ at 300 years. At a distance of about 200 feet above and below the mine level, peak temperatures of about $120^{\circ} \mathrm{C}$ occur about 100 years after waste implacement. At increased distances from the disposal horizon, peak temperatures are much reduced and occur at much later times. 
Nuclide Migration

Over the very long time spans involved, it is really the geologic formation which "contains" the waste materials. For disposal in salt formations, the waste is contained within a solid massive salt body, portions of which have been recrystallized by plastic deformation of the salt due to overburden pressures and elevated temperatures. The migration of radionuclides through solid salt has been investigated both theoretically and experimentally. The results of these studies indicated that solid-solid diffusion rates were so slow that migration of the nuclides was insignificant. Under the most adverse assumptions (including alpha recoil as a part of the driving function) surface diffusion of radionuclides along the boundaries of the salt grains would be limited to about $20, \mathrm{~cm}$ per million years.

Nuciide migration is also used to refer to the migration of dissolved radionuclides along with the migration of the solvent (usually water). In this case, an important factor is the high affinity for fission product ions to be chemisorbed on many natural minerals, especially the clay minerals universally found in soils, shales mudstones, etc. This chemisorption serves to retard the rate of movement of the radionuclide by a significant factor below that of the migrating water. For geologic waste disposal, the rock type and location are chosen so that the wastes will be isolated from circulating groundwater. Therefore this type of nuclide migration phenomena does not become a direct issue. However, the sorption properties of the rock formations surrounding will be determined during the geologic investigations for use in subsequent safety analysis. 
These safety analysis serve to predict the consequences of a hypothetical failure of the geologic containment. Whenever the hypothetical failure involves a release pathway which includes the leaching of the wastes and return of solutions to the surface, sorption of the radionuclides significantly delays the release (allowing more time for radioactive decay). and slows the rate of the release. 


\section{Continental Glaciation}

The Great Lakes region of the United States has been subjected to repeated episodes of continental glaciation in the recent geological past. There is every reason to believe that we are currently experiencing a normal interglacial period and that the future promises renewed episodes of glaciation. Continental glaciers certainly reshape the surface terrain by scraping off the soil and unconsolidated materials when advancing and redepositing them when retreating. However, for continental glaciers, the erosional phase of this erosional/depositional process does not extend to depths of more than two to three hundred feet, certainly well above the minimum waste repository depth. One of the special geological investigations to be undertaken as a part of any area studies in the Salina Salt Basin will be the thorough analys is of the effects of previous giaciations and a prediction of the possible adverse affects of repanted future episodes of glaciation. 


\section{Retrievability Requirements}

The plan is that any geologic terminal storage facility would be operated as a pilot plant for the first several years. In this case, pilot plant means that (1) only a limited quantity of waste will be implaced, (2) a number of design confirmation experiments will be carried out, and (3) all of the waste emplaced will be readily and easily retrievable. We interpret "readily and easily retrievable" to mean that the wastes can be removed from the underground excavations at a cost and handling rate not significantly greater than that for emplacement of the waste. Although the design concepts to achieve this retrievability have not yet been worked out in detail, it is possible to identify some of the requirements which must be met. First, the waste packaging must remain intact, especially in the face of corrosive chloride environment, Second, for high-level wastes, some provision must be made to prevent plastic flow of the salt from closing around the canister. One of the methods under development to accomplish both of these objectives is to line or case the hole with some kind of liner which would both retain the salt flowage and prevent direct contact of salt with the waste canister. Third, we feel that the definition of retrievability effectively requires the use of the same handling equipment and procedures (operating in reverse) as use for the waste emplacement. Provision for this reverse mode operation must be made in the initial design of the equipment and physical facilities. Finally, the excavated storage rooms will not be backfilled and sealed as would be the case for actual disposal operations. Since ready access to the storage rooms will be required for an extended period of time, considerable care must be taken in their structural design and it may be necessary to install appropriate artificial supports. 

K. K. Aydelotte
A. L. Boch
G. D. Brunton
H. C. Claiborne
H. I. Cobert
G. H. Jenks
R. B. Laughon
T. F. Lomenick
R. S. Lowrie
S. C. Matthews
L. L. McCauley
W. C. McClain
J. R. Palmer
A. S. Quist
N. H. Rosenberg
W. K. Russe11
R. B. Schappe 1
M. L. Shell
D. W. Turner
J. E. Vath
C. D. Zerby
File - RC (2) 